\title{
Asymmetric Direct 1,2-Addition of Aryl Grignard Reagents to Aryl Alkyl Ketones
}

\author{
Kazuki Osakama and Makoto Nakajima \\ Graduate School of Pharmaceutical Sciences, Kumamoto University, \\ 5-1 Oe-honmachi, Chuo-Ku, Kumamoto 862-0973, Japan
}

\section{Supporting Information}

\section{Table of Contents}

$\begin{array}{lr}\text { General Methods } & \text { S-2 }\end{array}$

$\begin{array}{lr}\text { Solvents and Chemicals } & \text { S-2 }\end{array}$

$\begin{array}{lr}\text { Preparation of Ligands } & \text { S-3 }\end{array}$

Typical Procedure; Asymmetric 1,2-Addition of Grignard Reagents S-13

$\begin{array}{lr}\text { Investigation of Nonlinear Effect } & \text { S-20 }\end{array}$

${ }^{1} \mathrm{H}$ and ${ }^{13} \mathrm{C}$ NMR Spectra of New Compounds $\quad$ S-21

$\begin{array}{lr}\text { HPLC Traces of Optically Active Compounds } & \text { S-28 }\end{array}$

$\begin{array}{lr}\text { References } & \text { S-41 }\end{array}$ 


\section{General Methods}

Melting points (Mp) are uncorrected. ${ }^{1} \mathrm{H}$ and ${ }^{13} \mathrm{C}$ NMR spectra were measured in $\mathrm{CDCl}_{3}$ with JEOL JNM-ECX400 spectrometer. Tetramethylsilane (TMS) ( $\delta=0 \mathrm{ppm})$ and $\mathrm{CDCl}_{3}(\delta$ $=77.0 \mathrm{ppm}$ ) served as internal standards for ${ }^{1} \mathrm{H}$ and ${ }^{13} \mathrm{C} \mathrm{NMR}$, respectively. Infrared spectra were recorded on JEOL JIR 6500-W. Mass spectra were measured with JEOL JMSDX303HF mass spectrometer. Optical rotations were recorded on JASCO P-1010 polarimeter. High-pressure liquid chromatography (HPLC) was performed on JASCO P-980 and UV-1575. Thin-layer chromatography (TLC) analysis was carried out using Merck silica gel plates. Visualization was accomplished with UV light and anisaldehyde. Column chromatography was performed using Kanto Chemical Silica Gel 60N (spherical, neutral, 63-210 $\mu \mathrm{m}$ ). All reactions were performed under argon atmosphere using glassware equipped with a rubber septum and a magnetic stirring bar.

\section{Solvents and Chemicals}

Dry tetrahydrofuran (dehydrated) was purchased from Kanto Chemical. All Grignard reagents were prepared from the corresponding aryl or alkyl bromide and $\mathrm{Mg}$ as approximately 1.5 $\mathrm{M} \mathrm{Et}_{2} \mathrm{O}$ or THF solution. Ligands 3a was purchased as a $(R)$-isomer and used without purification. Ligands $\mathbf{3} \mathbf{b}^{1}$ and $\mathbf{3} \mathbf{c}^{2}$, and ketone $\mathbf{1} \mathbf{f}^{3}$ were prepared by the literature methods. All other chemicals were purified based on standard procedures. 


\section{Preparation of Ligands}

ligand 3d

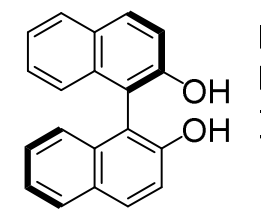

(R)-BINOL

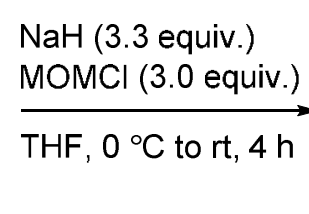

$\mathrm{OH}$

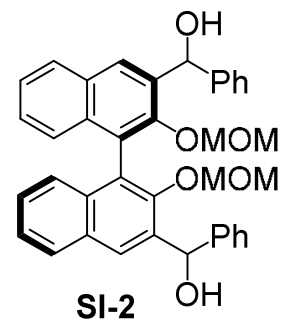

1. conc. $\mathrm{HCl}$ aq $\mathrm{CH}_{2} \mathrm{Cl}_{2} / \mathrm{MeOH}, \mathrm{rt}, 4 \mathrm{~h}$

2. $\mathrm{Et}_{3} \mathrm{SiH}$ (5.0 equiv.) $\mathrm{BF}_{3} \cdot \mathrm{OEt}_{2}$ (5.0 equiv.) $\mathrm{CH}_{2} \mathrm{Cl}_{2}, 0^{\circ} \mathrm{C}, 1 \mathrm{~h}$
1. ${ }^{n}$ BuLi (3.0 equiv.) $\mathrm{Et}_{2} \mathrm{O}, 0^{\circ} \mathrm{C}, 3 \mathrm{~h}$

2.<smiles></smiles>

SI-1 $94 \%$ yield

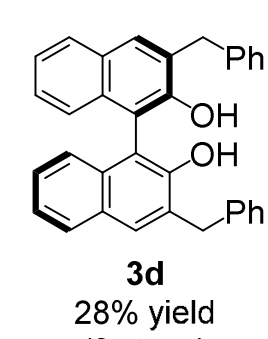

(3 steps)

(R)-2,2'-dihydroxy-1,1'-binaphthyl (10 g, $34.9 \mathrm{mmol}, 1.0$ equiv.) in THF (50 mL) was added via cannula to the suspension of $\mathrm{NaH}$ ( $4.6 \mathrm{~g}, 60 \%$ in oil, $115 \mathrm{mmol}, 3.3$ equiv.) in THF (150 $\mathrm{mL}$ ) under argon atmosphere at $0{ }^{\circ} \mathrm{C}$. The reaction mixture was warmed to room temperature and stirred for $1 \mathrm{~h}$. After the mixture was re-cooled to $0{ }^{\circ} \mathrm{C}$, chloromethyl methyl ether (8.5 $\mathrm{mL}, 105 \mathrm{mmol}, 3.0$ equiv.) was slowly added. The reaction mixture was warmed to room temperature and stirred for $3 \mathrm{~h}$. The reaction was quenched with sat. $\mathrm{NH}_{4} \mathrm{Cl}(20 \mathrm{~mL})$. After evaporation, the aqueous layer was extracted with $\mathrm{CH}_{2} \mathrm{Cl}_{2}(4 \times 20 \mathrm{~mL})$. The combined organic layers were washed with $\mathrm{H}_{2} \mathrm{O}(20 \mathrm{~mL})$, brine $(20 \mathrm{~mL})$ and dried over $\mathrm{Na}_{2} \mathrm{SO}_{4}$. After filtration and evaporation, the obtained crude product was washed with Hexane to furnish SI-1 as colorless needles (12.3 g, 94\%).

$n$-Butyl lithium (5.0 mL, $8.0 \mathrm{mmol}, 3.0$ equiv. $1.6 \mathrm{M}$ in $n$-hexane) was added to the solution of SI-1 (1.0 g, $2.7 \mathrm{mmol}, 1.0$ equiv.) in $\mathrm{Et}_{2} \mathrm{O}(30 \mathrm{~mL})$ under argon atmosphere at $0{ }^{\circ} \mathrm{C}$. The reaction mixture was stirred at the same temperature for $3 \mathrm{~h}$ and then benzaldehyde $(0.84 \mathrm{~mL}$, $8.0 \mathrm{mmol}, 3.0$ equiv.) was added. The reaction mixture was warmed to room temperature and stirred for $2 \mathrm{~h}$. The reaction was quenched with sat. $\mathrm{NH}_{4} \mathrm{Cl}(10 \mathrm{~mL})$ and then the aqueous layer was extracted with EtOAc $(4 \times 20 \mathrm{~mL})$. The combined organic layers were washed with brine $(20 \mathrm{~mL})$ and dried over $\mathrm{Na}_{2} \mathrm{SO}_{4}$. After filtration and evaporation, the obtained crude product was purified by column chromatography (Hexane/EtOAc $=6 / 1-1 / 1, \mathrm{SiO}_{2} 40 \mathrm{~g}$ ) to furnish SI$\mathbf{2}$ as a diastereomeric mixture (1.553 g).

$12 \mathrm{~N} \mathrm{HCl}$ (5 drops) was added to the solution of SI-2 (1.553 g) in $\mathrm{MeOH}(10 \mathrm{~mL})$ and $\mathrm{CH}_{2} \mathrm{Cl}_{2}$ $(5 \mathrm{~mL})$ at room temperature. After the reaction mixture was stirred for $4 \mathrm{~h}$, the reaction was 
quenched with sat. $\mathrm{NaHCO}_{3}(5 \mathrm{~mL})$ and $\mathrm{H}_{2} \mathrm{O}(5 \mathrm{~mL})$. The aqueous layer was extracted with $\mathrm{CH}_{2} \mathrm{Cl}_{2}(4 \times 20 \mathrm{~mL})$. The combined organic layers were washed with brine $(20 \mathrm{~mL})$ and dried over $\mathrm{Na}_{2} \mathrm{SO}_{4}$. Filtration and evaporation afforded the tetraol $(1.33 \mathrm{~g})$ as a diastereomeric mixture. The tetraol was used in the next reaction without further purification.

Triethylsilane (1.6 mL, $10 \mathrm{mmol}, 5.0$ equiv.) was added to the solution of the above tetraol (1.0 g, $2 \mathrm{mmol}, 1.0$ equiv.) and boron trifluoride etherate (1.2 mL, $10 \mathrm{mmol}, 5.0$ equiv.) in $\mathrm{CH}_{2} \mathrm{Cl}_{2}(5 \mathrm{~mL})$ under argon atmosphere at $0{ }^{\circ} \mathrm{C}$. The reaction mixture was stirred for $1 \mathrm{~h}$, and then the reaction was quenched with sat. $\mathrm{NaHCO}_{3}(10 \mathrm{~mL})$. The aqueous layer was extracted with $\mathrm{CH}_{2} \mathrm{Cl}_{2}(4 \times 20 \mathrm{~mL})$. The combined organic layers were washed with brine $(20 \mathrm{~mL})$ and dried over $\mathrm{Na}_{2} \mathrm{SO}_{4}$. After filtration and evaporation, the obtained crude product was purified by column chromatography (Hexane/EtOAc $=10 / 1, \mathrm{SiO}_{2} 20 \mathrm{~g}$ ) to furnish the product $\mathbf{3 d}$ as colorless needles (349 mg, 28\% in 3 steps).

\section{(R)-3,3'-Dibenzyl-2,2'-dihydroxy-1,1'-binaphthyl (3d)}

Colorless needles.

Mp: $76.0-77.0{ }^{\circ} \mathrm{C}$.

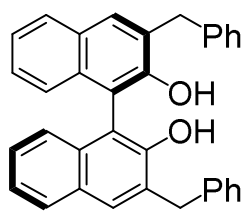

TLC: $R_{f} 0.54$ (Hexane/EtOAc $=4 / 1$, stained blue with anisaldehyde).

$[\alpha]_{\mathrm{D}}^{29}+69.8\left(c 1.05, \mathrm{CHCl}_{3}\right)$.

IR (ATR): 3502, 3026, 748, $696 \mathrm{~cm}^{-1}$.

${ }^{1} \mathrm{H}$ NMR (400 MHz, $\mathrm{CDCl}_{3}$ ): $\delta 4.23$ (s, 4H), 5.16 (s, 2H, OH), $7.08(\mathrm{~d}, J=8.2 \mathrm{~Hz}, 2 \mathrm{H}, \mathrm{Ar} H$ ), 7.22-7.28 (m, 4H, ArH), 7.30-7.35 (m, 10H, ArH), 7.69 (s, 2H, ArH), 7.78 (d, J=8.2 Hz, 2H, $\operatorname{Ar} H)$.

${ }^{13} \mathrm{C}$ NMR $\left(100 \mathrm{MHz}, \mathrm{CDCl}_{3}\right): \delta 36.6,110.9,123.9,124.0,126.2,126.7,128.0,128.5,129.1$, $129.3,130.1,130.8,132.2,140.0,151.5$.

MS (EI): $m / z 466\left(\mathrm{M}^{+}\right)$.

HRMS: Calcd for $\mathrm{C}_{34} \mathrm{H}_{26} \mathrm{O}_{2} 466.1933$, found 466.1917. 


\section{ligand 3e}

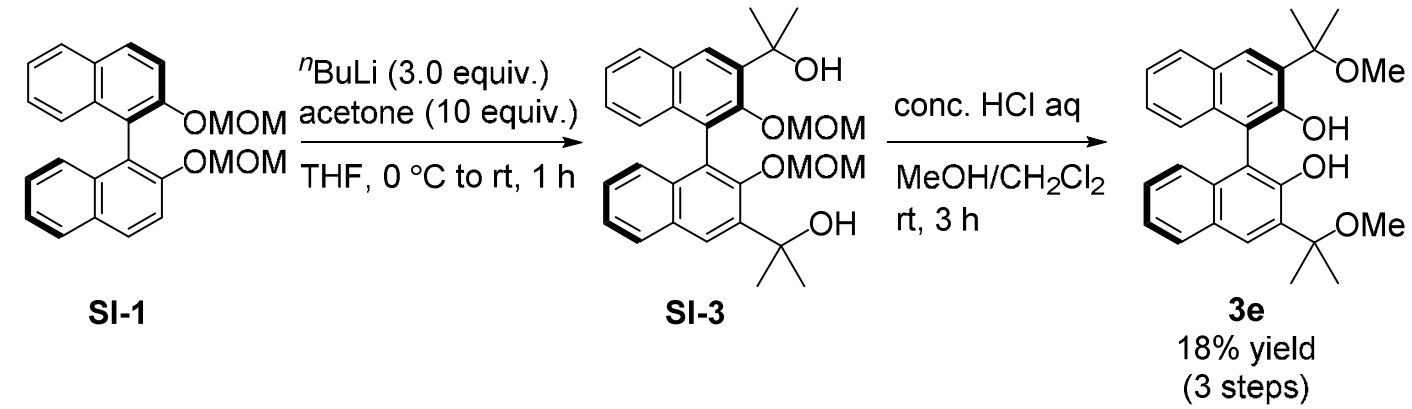

$n$-Butyl lithium (9.4 mL, $15 \mathrm{mmol}, 3.0$ equiv. $1.6 \mathrm{M}$ in $n$-hexane) was added to the solution of SI-1 (1.87 g, 5.0 mmol, 1.0 equiv.) in THF $(25 \mathrm{~mL})$ under argon atmosphere at $0{ }^{\circ} \mathrm{C}$. The reaction mixture was stirred at the same temperature for $1 \mathrm{~h}$ and then acetone $(3.7 \mathrm{~mL}, 50$ mmol, 10 equiv.) was added. The reaction mixture was warmed to room temperature and stirred for $10 \mathrm{~min}$. The reaction was quenched with sat. $\mathrm{NH}_{4} \mathrm{Cl}(10 \mathrm{~mL})$ and then the aqueous layer was extracted with EtOAc $(4$ x $20 \mathrm{~mL})$. The combined organic layers were washed with brine $(20 \mathrm{~mL})$ and dried over $\mathrm{Na}_{2} \mathrm{SO}_{4}$. After filtration and evaporation, the obtained crude product was purified by column chromatography (Hexane/EtOAc $\left.=4 / 1-1 / 1, \mathrm{SiO}_{2} 50 \mathrm{~g}\right)$ to furnish SI-3 as colorless needles (911 mg).

$12 \mathrm{~N} \mathrm{HCl}$ (10 drops) was added to the solution of SI-3 $(911 \mathrm{mg})$ in $\mathrm{MeOH}(10 \mathrm{~mL})$ and $\mathrm{CH}_{2} \mathrm{Cl}_{2}(5 \mathrm{~mL})$ at room temperature. After the reaction mixture was stirred for $3 \mathrm{~h}$, the reaction was quenched with sat. $\mathrm{NaHCO}_{3}(10 \mathrm{~mL})$ and $\mathrm{H}_{2} \mathrm{O}(5 \mathrm{~mL})$. The aqueous layer was extracted with $\mathrm{CH}_{2} \mathrm{Cl}_{2}(4 \times 20 \mathrm{~mL})$. The combined organic layers were washed with brine (20 $\mathrm{mL}$ ) and dried over $\mathrm{Na}_{2} \mathrm{SO}_{4}$. After filtration and evaporation, the obtained crude product was purified by column chromatography (Hexane $/ \mathrm{CH}_{2} \mathrm{Cl}_{2}=1 / 1-0 / 1, \mathrm{SiO}_{2} 20 \mathrm{~g}$ ) to furnish the BINOL derivative $\mathbf{3 e}$ as colorless needles (381 mg, 18\% in 3 steps).

\section{(R)-3,3'-Bis(1-methoxy-1-methylethyl)-2,2'-dihydroxy-1,1'-binaphthyl (3e)}

\section{Colorless needles.}

Mp: $224.0-226.0^{\circ} \mathrm{C}$.

TLC: $R_{f} 0.38$ (Hexane/EtOAc $=4 / 1$, stained blue with anisaldehyde).

$[\alpha]_{\mathrm{D}}{ }^{31}+219.9\left(c 1.00, \mathrm{CHCl}_{3}\right)$.

IR (ATR): 3181, 2979, 1199, 1049, 751, $662 \mathrm{~cm}^{-1}$.

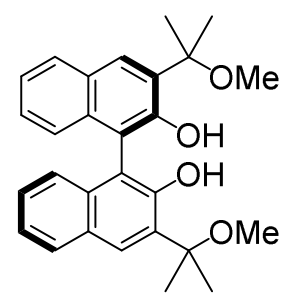

${ }^{1} \mathrm{H}$ NMR (400 MHz, $\mathrm{CDCl}_{3}$ ): $\delta 1.80(\mathrm{~s}, 12 \mathrm{H}), 3.29$ (s, 6H), 7.14-7.31 (m, 6H, ArH), 7.72 (s, 2H, ArH), $7.81(\mathrm{~d}, J=8.2 \mathrm{~Hz}, 2 \mathrm{H}, \mathrm{ArH}), 8.93(\mathrm{~s}, 2 \mathrm{H}, \mathrm{OH})$. 
${ }^{13} \mathrm{C}$ NMR $\left(100 \mathrm{MHz}, \mathrm{CDCl}_{3}\right): \delta 26.5,26.8,51.0,80.4,117.3,123.1,124.6,126.4,128.0$, $128.1,130.6,133.8,151.6$ (one carbon overlapped).

MS (EI): $m / z 430\left(\mathrm{M}^{+}\right)$.

HRMS: Calcd for $\mathrm{C}_{28} \mathrm{H}_{30} \mathrm{O}_{4} 430.2144$, found 430.2133 .

\section{ligand $3 f$}

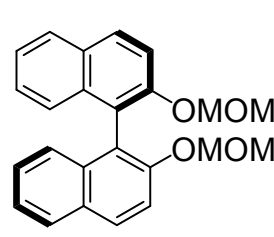

SI-1
${ }^{n}$ BuLi (2.6 equiv.) isobutylene oxide (5.0 equiv.)

$\mathrm{THF}, 0{ }^{\circ} \mathrm{C}$ to $\mathrm{rt}, 21 \mathrm{~h}$

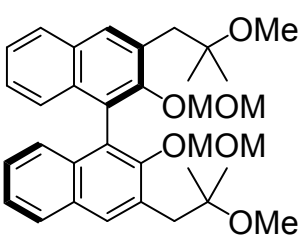

SI-5

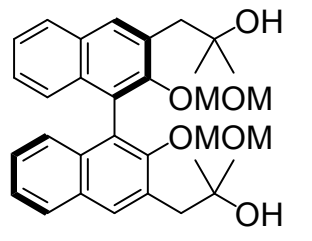

SI-4

$76 \%$ yield

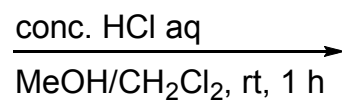

$\mathrm{NaH}$ (3.0 equiv.)

Mel (4.0 equiv.)

$\mathrm{THF}, 0^{\circ} \mathrm{C}$ to $\mathrm{rt}, 4 \mathrm{~h}$

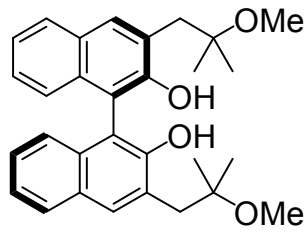

$3 \mathbf{f}$

$98 \%$ yield

(2 steps)

$n$-Butyl lithium (26 mL, $42 \mathrm{mmol}, 2.6$ equiv. $1.6 \mathrm{M}$ in $n$-hexane) was added to the solution of SI-1 (6.0 g, $16 \mathrm{mmol}, 1.0$ equiv.) in THF $(80 \mathrm{~mL})$ under argon atmosphere at $0{ }^{\circ} \mathrm{C}$. The reaction mixture was stirred at the same temperature for $3 \mathrm{~h}$ and then isobutylene oxide (7.1 $\mathrm{mL}, 80 \mathrm{mmol}, 5.0$ equiv.) was added. The reaction mixture was warmed to room temperature and stirred for $18 \mathrm{~h}$. The reaction was quenched with sat. $\mathrm{NH}_{4} \mathrm{Cl}(20 \mathrm{~mL})$. After evaporation, the aqueous layer was extracted with $\mathrm{CH}_{2} \mathrm{Cl}_{2}(4 \times 20 \mathrm{~mL})$. The combined organic layers were washed with $\mathrm{H}_{2} \mathrm{O}(20 \mathrm{~mL})$, brine $(20 \mathrm{~mL})$ and dried over $\mathrm{Na}_{2} \mathrm{SO}_{4}$. After filtration and evaporation, the obtained crude product was purified by column chromatography $\left(\right.$ Hexane/EtOAc $\left.=3 / 1-1 / 1, \mathrm{SiO}_{2} 200 \mathrm{~g}\right)$ to furnish $\mathbf{S I}-4$ as colorless needles $(6.3 \mathrm{~g}, 76 \%)$.

SI-4 (6.3 g, $12.1 \mathrm{mmol}, 1.0$ equiv.) in THF (50 mL) was added to the suspension of $\mathrm{NaH}(1.46$ $\mathrm{g}, 60 \%$ in oil, $36.4 \mathrm{mmol}, 3.0$ equiv. $)$ in THF (40 mL) under argon atmosphere at $0{ }^{\circ} \mathrm{C}$. The reaction mixture was warmed to room temperature and stirred for $1 \mathrm{~h}$. Methyl iodide $(3.0 \mathrm{~mL}$, $48.5 \mathrm{mmol}, 4.0$ equiv.) was added to the mixture, and then the reaction mixture was stirred for $3 \mathrm{~h}$. The reaction was quenched with sat. $\mathrm{NH}_{4} \mathrm{Cl}(20 \mathrm{~mL})$. After evaporation, the aqueous layer was extracted with $\mathrm{CH}_{2} \mathrm{Cl}_{2}(4 \times 20 \mathrm{~mL})$. The combined organic layers were washed with $\mathrm{H}_{2} \mathrm{O}$ $(20 \mathrm{~mL})$, brine $(20 \mathrm{~mL})$ and dried over $\mathrm{Na}_{2} \mathrm{SO}_{4}$. After filtration and evaporation, the crude product SI-5 was obtained as colorless needles. 
$12 \mathrm{~N} \mathrm{HCl}$ (5 drops) was added to the solution of $\mathbf{S I - 5}$ in $\mathrm{MeOH}(30 \mathrm{~mL})$ and $\mathrm{CH}_{2} \mathrm{Cl}_{2}(10 \mathrm{~mL})$ at room temperature. After the reaction mixture was stirred for $1 \mathrm{~h}$, the reaction was quenched with sat. $\mathrm{NaHCO}_{3}(10 \mathrm{~mL})$ and $\mathrm{H}_{2} \mathrm{O}(5 \mathrm{~mL})$. The aqueous layer was extracted with $\mathrm{CH}_{2} \mathrm{Cl}_{2}(4$ x $20 \mathrm{~mL})$. The combined organic layers were washed with brine $(20 \mathrm{~mL})$ and dried over $\mathrm{Na}_{2} \mathrm{SO}_{4}$. After filtration and evaporation, the obtained crude product was purified by column chromatography (Hexane/ $\mathrm{CH}_{2} \mathrm{Cl}_{2}=1 / 1-0 / 1, \mathrm{SiO}_{2} 120 \mathrm{~g}$ ) to furnish the BINOL derivative $\mathbf{3 f}$ as colorless needles ( $5.5 \mathrm{~g}, 98 \%$ in 2 steps).

\section{(R)-3,3'-Bis(2-methoxy-2-methylpropyl)-2,2'-dihydroxy-1,1'-binaphthyl (3f)}

Colorless needles.

Mp: $148.0-149.5^{\circ} \mathrm{C}$.

TLC: $R_{f} 0.24$ (Hexane/EtOAc $=4 / 1$, stained purple with anisaldehyde).

$[\alpha]_{\mathrm{D}}{ }^{31}+132.7\left(c 1.00, \mathrm{CHCl}_{3}\right)$.

IR (ATR): 3152, 2978, 1262, 1061, 748, $633 \mathrm{~cm}^{-1}$.

${ }^{1} \mathrm{H}$ NMR (400 MHz, $\left.\mathrm{CDCl}_{3}\right): \delta 1.27(\mathrm{~s}, 6 \mathrm{H}), 1.32(\mathrm{~s}, 6 \mathrm{H}), 3.03(\mathrm{~d}, J=14 \mathrm{~Hz}, 2 \mathrm{H}), 3.22(\mathrm{~d}, J=$ $14 \mathrm{~Hz}, 2 \mathrm{H}), 3.22$ (s, 6H), 7.11-7.19 (m, 4H, ArH), 7.23-7.28 (m, 2H, ArH), 7.64 (s, 2H, ArH), 7.77 (d, $J=7.8 \mathrm{~Hz}, 2 \mathrm{H}, \mathrm{ArH}), 8.50(\mathrm{~s}, 2 \mathrm{H}, \mathrm{OH})$.

${ }^{13} \mathrm{C}$ NMR $\left(100 \mathrm{MHz}, \mathrm{CDCl}_{3}\right): \delta 23.6,24.3,46.1,49.5,77.7,117.6,122.9,124.9,125.6,127.5$, $128.6,131.3,133.5,152.1$ (one carbon overlapped).

MS (EI): $m / z 458\left(\mathrm{M}^{+}\right)$.

HRMS: Calcd for $\mathrm{C}_{30} \mathrm{H}_{34} \mathrm{O}_{4} 458.2457$, found 458.2436.

\section{ligand $3 g$}

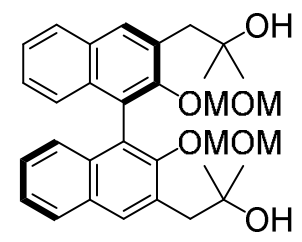

SI-4

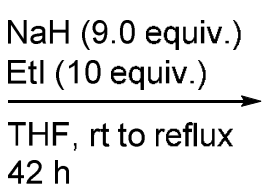
$42 \mathrm{~h}$

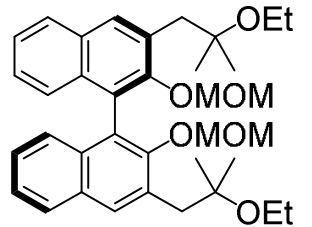

SI-6

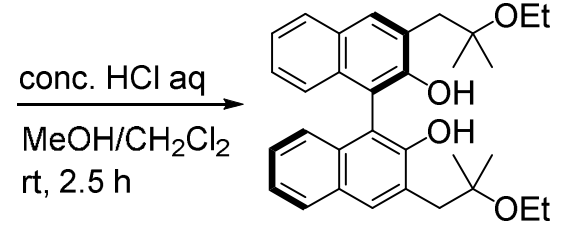

$3 \mathrm{~g}$ $26 \%$ yield (2 steps)

SI-4 (4.43 g, $8.54 \mathrm{mmol}, 1.0$ equiv.) in THF (30 mL) was added to the suspension of $\mathrm{NaH}(3.1$ $\mathrm{g}, 60 \%$ in oil, $76.9 \mathrm{mmol}, 9.0$ equiv.) in THF $(30 \mathrm{~mL})$ under argon atmosphere at $0{ }^{\circ} \mathrm{C}$. The reaction mixture was warmed to room temperature and stirred for $1 \mathrm{~h}$. Ethyl iodide $(2.73 \mathrm{~mL}$, $85.4 \mathrm{mmol}, 10$ equiv.) was added to the mixture, and then the reaction mixture was stirred for $41 \mathrm{~h}$ at reflux. The reaction was quenched with sat. $\mathrm{NH}_{4} \mathrm{Cl}(20 \mathrm{~mL})$. After evaporation, the 
aqueous layer was extracted with $\mathrm{CH}_{2} \mathrm{Cl}_{2}(4 \times 20 \mathrm{~mL})$. The combined organic layers were washed with $\mathrm{H}_{2} \mathrm{O}(20 \mathrm{~mL})$, brine $(20 \mathrm{~mL})$ and dried over $\mathrm{Na}_{2} \mathrm{SO}_{4}$. After filtration and evaporation, the obtained crude product was purified by column chromatography $\left(\right.$ Hexane/EtOAc $\left.=6 / 1-4 / 1-0 / 1, \mathrm{SiO}_{2} 120 \mathrm{~g}\right)$ to furnish SI-6 as colorless needles $(2.78 \mathrm{~g})$.

$12 \mathrm{~N} \mathrm{HCl}$ (5 drops) was added to the solution of SI-6 in $\mathrm{MeOH}(10 \mathrm{~mL})$ and $\mathrm{CH}_{2} \mathrm{Cl}_{2}(5 \mathrm{~mL})$ at room temperature. After the reaction mixture was stirred for $2.5 \mathrm{~h}$, the reaction was quenched with sat. $\mathrm{NaHCO}_{3}(10 \mathrm{~mL})$ and $\mathrm{H}_{2} \mathrm{O}(5 \mathrm{~mL})$. The aqueous layer was extracted with $\mathrm{CH}_{2} \mathrm{Cl}_{2}(4 \times 20 \mathrm{~mL})$. The combined organic layers were washed with brine $(20 \mathrm{~mL})$ and dried over $\mathrm{Na}_{2} \mathrm{SO}_{4}$. After filtration and evaporation, the obtained crude product was purified by column chromatography (Hexane $/ \mathrm{CH}_{2} \mathrm{Cl}_{2}=1 / 1-0 / 1, \mathrm{SiO}_{2} 120 \mathrm{~g}$ ) to furnish the BINOL derivative $\mathbf{3 g}$ as colorless needles (1.08 $\mathrm{g}, 26 \%$ in 2 steps).

\section{(R)-3,3'-Bis(2-ethoxy-2-methylpropyl)-2,2'-dihydroxy-1,1'-binaphtyl (3g)}

Colorless needles.

Mp: $74.5-76.0{ }^{\circ} \mathrm{C}$.

TLC: $R_{f} 0.44$ (Hexane/EtOAc $=4 / 1$, stained purple with anisaldehyde).

$[\alpha]_{\mathrm{D}}{ }^{30}+215.0\left(c 1.00, \mathrm{CHCl}_{3}\right)$.

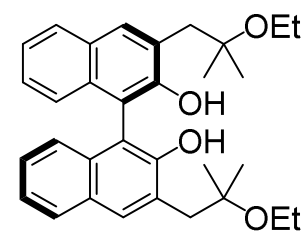

IR (ATR): 3177, 2973, 1259, 1058, 746, $662 \mathrm{~cm}^{-1}$.

${ }^{1} \mathrm{H}$ NMR (400 MHz, $\left.\mathrm{CDCl}_{3}\right): \delta 1.05\left(\mathrm{t}, J=6.9 \mathrm{~Hz}, 6 \mathrm{H},\left(-\mathrm{OCH}_{2} \mathrm{CH}_{3}\right)_{2}\right), 1.29(\mathrm{~s}, 6 \mathrm{H}), 1.33$ (s, $6 \mathrm{H}), 3.00(\mathrm{~d}, J=14 \mathrm{~Hz}, 2 \mathrm{H}), 3.19(\mathrm{~d}, J=14 \mathrm{~Hz}, 2 \mathrm{H}), 3.45\left(\mathrm{q}, J=6.9 \mathrm{~Hz}, 4 \mathrm{H},\left(-\mathrm{OCH}_{2} \mathrm{CH}_{3}\right)_{2}\right)$, 7.12-7.17 (m, 4H, ArH), 7.22-7.27 (m, 2H, ArH), 7.63 (s, 2H, ArH), 7.76 (d, J=8.2 Hz, 2H, $\mathrm{Ar} H), 8.53$ (s, 2H, OH).

${ }^{13} \mathrm{C}$ NMR (100 MHz, $\left.\mathrm{CDCl}_{3}\right): \delta 15.7,24.1,25.0,46.5,57.4,77.6,117.9,122.8,125.0,125.4$, $127.4,127.7,128.6,131.1,133.5,152.1$.

MS (EI): $m / z 487\left(\mathrm{M}+\mathrm{H}^{+}\right)$.

HRMS: Calcd for $\mathrm{C}_{32} \mathrm{H}_{38} \mathrm{O}_{4} 486.2770$, found 486.2759. 


\section{ligand $3 h$}

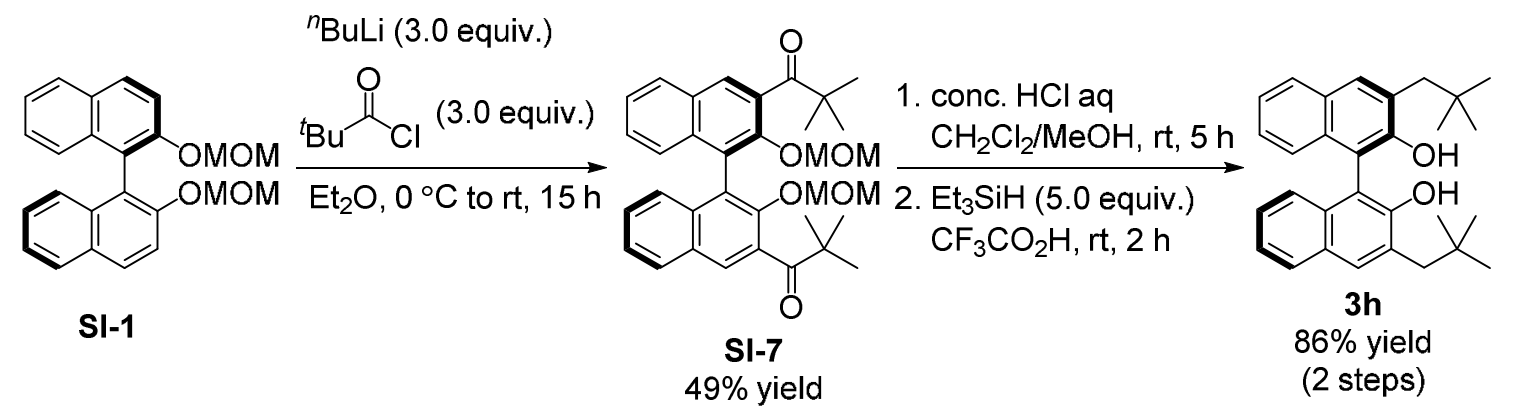

$n$-Butyl lithium (5.0 mL, $8.0 \mathrm{mmol}, 3.0$ equiv. $1.6 \mathrm{M}$ in $n$-hexane) was added to the solution of SI-1 (1.0 g, $2.7 \mathrm{mmol}, 1.0$ equiv.) in $\mathrm{Et}_{2} \mathrm{O}(30 \mathrm{~mL})$ under argon atmosphere at $0{ }^{\circ} \mathrm{C}$. The reaction mixture was stirred at the same temperature for $3 \mathrm{~h}$ and then pivaloyl chloride (1.0 $\mathrm{mL}, 8.0 \mathrm{mmol}, 3.0$ equiv.) was added. The reaction mixture was warmed to room temperature and stirred for $12 \mathrm{~h}$. The reaction was quenched with sat. $\mathrm{NH}_{4} \mathrm{Cl}(10 \mathrm{~mL})$ and then the aqueous layer was extracted with EtOAc ( 4 x $20 \mathrm{~mL})$. The combined organic layers were washed with brine $(20 \mathrm{~mL})$ and dried over $\mathrm{Na}_{2} \mathrm{SO}_{4}$. After filtration and evaporation, the obtained crude product was purified by column chromatography (Hexane $/ \mathrm{CH}_{2} \mathrm{Cl}_{2}=1 / 1-0 / 1, \mathrm{SiO}_{2} 40 \mathrm{~g}$ ) to furnish SI-7 as colorless needles (704 mg, 49\%).

$12 \mathrm{~N} \mathrm{HCl}$ (5 drops) was added to the solution of SI-7 (704 mg, $1.3 \mathrm{mmol}, 1.0$ equiv.) in $\mathrm{MeOH}(10 \mathrm{~mL})$ and $\mathrm{CH}_{2} \mathrm{Cl}_{2}(5 \mathrm{~mL})$ at room temperature. After the reaction mixture was stirred for $5 \mathrm{~h}$, the reaction was quenched with sat. $\mathrm{NaHCO}_{3}(5 \mathrm{~mL})$ and $\mathrm{H}_{2} \mathrm{O}(5 \mathrm{~mL})$. The aqueous layer was extracted with $\mathrm{CH}_{2} \mathrm{Cl}_{2}(4 \times 20 \mathrm{~mL})$. The combined organic layers were washed with brine $(20 \mathrm{~mL})$ and dried over $\mathrm{Na}_{2} \mathrm{SO}_{4}$. Filtration and evaporation afforded the diol $(641.3 \mathrm{mg})$ as colorless needles. The diol was used in the next reaction without further purification.

Triethylsilane ( $1.1 \mathrm{~mL}, 6.5 \mathrm{mmol}, 5.0$ equiv.) was added to the solution of the above diol (641.3 mg, $1.3 \mathrm{mmol}, 1.0$ equiv.) in TFA ( $2 \mathrm{~mL})$ under argon atmosphere at room temperature. The reaction mixture was stirred for $2 \mathrm{~h}$, and then the reaction was quenched with sat. $\mathrm{NaHCO}_{3}(10 \mathrm{~mL})$. The aqueous layer was extracted with $\mathrm{CH}_{2} \mathrm{Cl}_{2}(4 \times 20 \mathrm{~mL})$. The combined organic layers were washed with brine $(20 \mathrm{~mL})$ and dried over $\mathrm{Na}_{2} \mathrm{SO}_{4}$. After filtration and evaporation, the obtained crude product was purified by column chromatography (Hexane/ $\mathrm{CH}_{2} \mathrm{Cl}_{2}=15 / 1-1 / 1, \mathrm{SiO}_{2} 20 \mathrm{~g}$ ) to furnish the product $\mathbf{3 h}$ as colorless needles ( $477 \mathrm{mg}, 86 \%$ in 2 steps). 
(R)-3,3'-Bis(2,2-dimethylpropyl)-2,2'-dihydroxy-1,1'-binaphthyl (3h)

Colorless needles.

Mp: $79.0-81.0^{\circ} \mathrm{C}$.

TLC: $R_{f} 0.68$ (Hexane/EtOAc $=4 / 1$, stained purple with anisaldehyde).

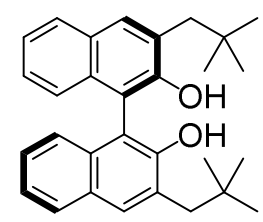

$[\alpha]_{\mathrm{D}}^{32}+70.6\left(c 1.00, \mathrm{CHCl}_{3}\right)$.

IR (ATR): 3521, 2948, 747, $660 \mathrm{~cm}^{-1}$.

${ }^{1} \mathrm{H}$ NMR (400 MHz, $\left.\mathrm{CDCl}_{3}\right): \delta 1.01(\mathrm{~s}, 18 \mathrm{H}), 2.77(\mathrm{~d}, J=13 \mathrm{~Hz}, 2 \mathrm{H}), 2.88$ (d, $\left.J=13 \mathrm{~Hz}, 2 \mathrm{H}\right)$, 5.09 (s, 2H, OH), 7.07 (d, $J=8.2 \mathrm{~Hz}, 2 \mathrm{H}, \operatorname{Ar} H), 7.21-7.27$ (m, 2H, ArH), 7.31-7.37 (m, 2H, $\operatorname{ArH}), 7.76(\mathrm{~s}, 2 \mathrm{H}, \mathrm{ArH}), 7.85(\mathrm{~d}, J=8.2 \mathrm{~Hz}, 2 \mathrm{H}, \mathrm{Ar} H)$.

${ }^{13} \mathrm{C}$ NMR $\left(100 \mathrm{MHz}, \mathrm{CDCl}_{3}\right): \delta 29.5,32.8,43.1,110.7,123.8,123.9,126.5,127.9,128.7$, $129.0,132.2,132.7,152.4$.

MS (EI): $m / z 426\left(\mathrm{M}^{+}\right)$.

HRMS: Calcd for $\mathrm{C}_{30} \mathrm{H}_{34} \mathrm{O}_{2} 426.2559$, found 426.2547 .

\section{ligand $3 i$ and 7}

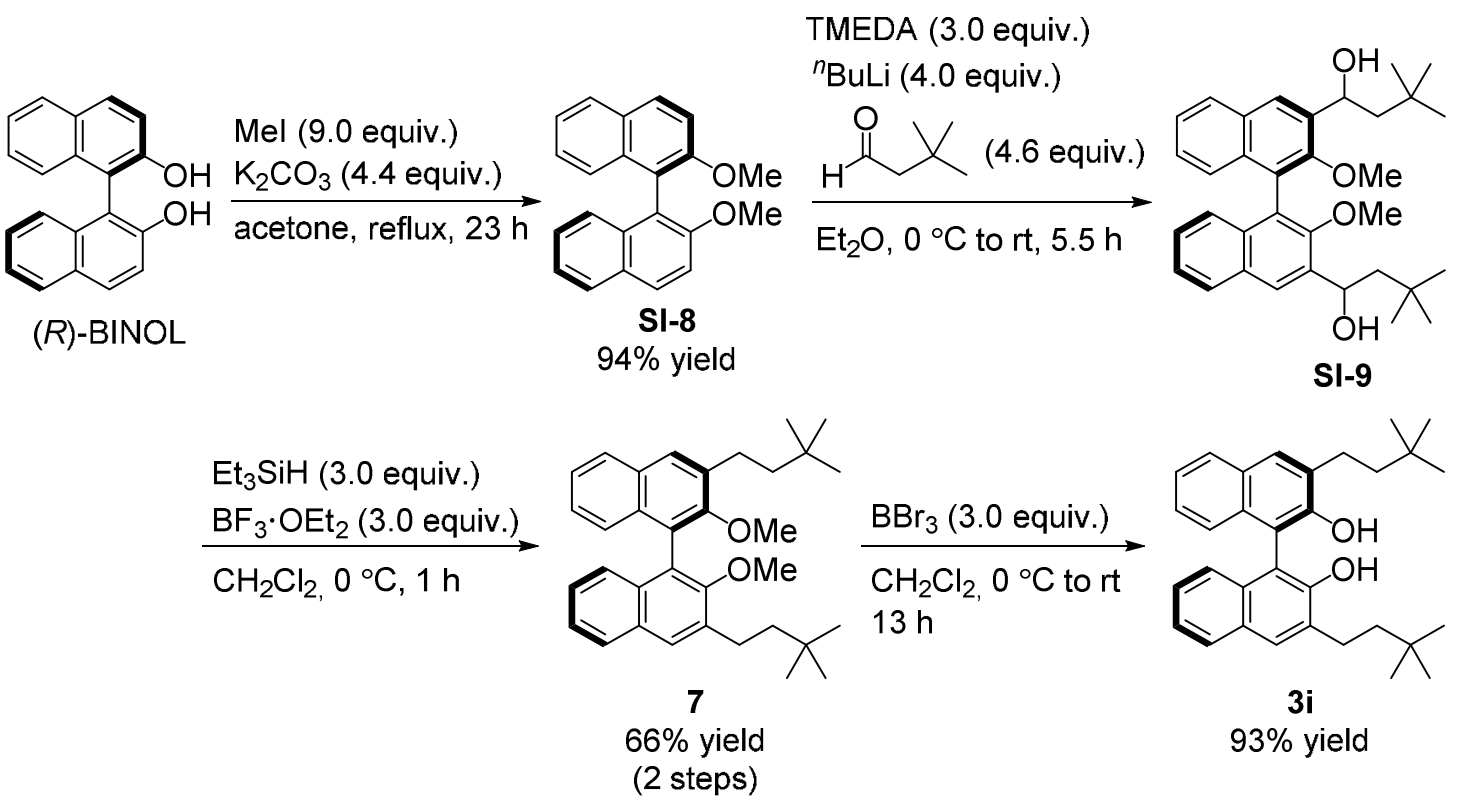

MeI (16 mL, $251 \mathrm{mmol}, 9.0$ equiv.) was added to the solution of $(R)-2,2$ '-dihydroxy-1,1'binaphthyl (8 g, 27.9 mmol, 1.0 equiv.) and $\mathrm{K}_{2} \mathrm{CO}_{3}$ (17 g, 123 mmol, 4.4 equiv.) in acetone $(60 \mathrm{~mL})$ under argon atmosphere at $\mathrm{rt}$. The reaction mixture was warmed to reflux and stirred for $23 \mathrm{~h}$. After filtration through celite and evaporation, the obtained crude product was washed with Hexane to furnish SI-8 as colorless needles (8.3 g, 94\%). 
$n$-Butyl lithium (16 mL, $25.4 \mathrm{mmol}, 4.0$ equiv. $1.6 \mathrm{M}$ in $n$-hexane) was added to the solution of TMEDA (2.9 mL, $19.1 \mathrm{mmol}, 3.0$ equiv.) in $\mathrm{Et}_{2} \mathrm{O}(125 \mathrm{~mL})$ under argon atmosphere at $0{ }^{\circ} \mathrm{C}$. The reaction mixture was stirred at room temperature for $0.5 \mathrm{~h}$ and then SI-8 $(2.0 \mathrm{~g}$, $6.36 \mathrm{mmol}, 1.0$ equiv.) was added. The mixture was stirred at the same temperature for $3 \mathrm{~h}$ and then 3,3-dimethylbutanal $(3.7 \mathrm{~mL}, 29.6 \mathrm{mmol}, 4.6$ equiv.) was added. The reaction mixture was stirred for $2 \mathrm{~h}$. The reaction was quenched with sat. $\mathrm{NH}_{4} \mathrm{Cl}(10 \mathrm{~mL})$ and then the aqueous layer was extracted with EtOAc $(4 \times 20 \mathrm{~mL})$. The combined organic layers were washed with $10 \% \mathrm{HCl}(20 \mathrm{~mL}), \mathrm{H}_{2} \mathrm{O}(20 \mathrm{~mL})$ and brine $(20 \mathrm{~mL})$ and dried over $\mathrm{Na}_{2} \mathrm{SO}_{4}$. Filtration and evaporation afforded SI-9 (3.83 g) as a diastereomeric mixture. SI-9 was used in the next reaction without further purification.

Boron trifluoride ethyl ether complex $(2.4 \mathrm{~mL}, 19.1 \mathrm{mmol}, 3.0$ equiv.) was added to the solution of SI-9 (3.83 g) and triethylsilane (3.1 mL, $19.1 \mathrm{mmol}, 3.0$ equiv.) in $\mathrm{CH}_{2} \mathrm{Cl}_{2}(60 \mathrm{~mL})$ under argon atmosphere at $0{ }^{\circ} \mathrm{C}$. The reaction mixture was stirred for $1 \mathrm{~h}$, and then the reaction was quenched with sat. $\mathrm{NaHCO}_{3}(10 \mathrm{~mL})$. The aqueous layer was extracted with $\mathrm{CH}_{2} \mathrm{Cl}_{2}(4 \times 20 \mathrm{~mL})$. The combined organic layers were washed with sat. $\mathrm{NaHCO}_{3}(20 \mathrm{~mL})$ and brine $(20 \mathrm{~mL})$, and dried over $\mathrm{Na}_{2} \mathrm{SO}_{4}$. After filtration and evaporation, the obtained crude product was purified by column chromatography (Hexane $/ \mathrm{CH}_{2} \mathrm{Cl}_{2}=10 / 1-4 / 1, \mathrm{SiO}_{2} 120$ g) to furnish 7 as colorless prisms $(2.11 \mathrm{~g}, 66 \%$ in 2 steps $)$.

Boron tribromide $(1.25 \mathrm{~mL}, 13.1 \mathrm{mmol}, 3.0$ equiv.) was added to the solution of $7(2.11 \mathrm{~g})$ in $\mathrm{CH}_{2} \mathrm{Cl}_{2}(45 \mathrm{~mL})$ under argon atmosphere at $0{ }^{\circ} \mathrm{C}$. The reaction mixture was stirred at room temperature for $13 \mathrm{~h}$, and then the reaction was quenched with $\mathrm{H}_{2} \mathrm{O}(20 \mathrm{~mL})$. The aqueous layer was extracted with $\mathrm{CH}_{2} \mathrm{Cl}_{2}(4 \times 20 \mathrm{~mL})$. The combined organic layers were washed with sat. $\mathrm{NaHCO}_{3}(20 \mathrm{~mL})$ and brine $(20 \mathrm{~mL})$, and dried over $\mathrm{Na}_{2} \mathrm{SO}_{4}$. After filtration and evaporation, the obtained crude product was purified by column chromatography (Hexane $/ \mathrm{CH}_{2} \mathrm{Cl}_{2}=10 / 1-1 / 1, \mathrm{SiO}_{2} 50 \mathrm{~g}$ ) to furnish $\mathbf{3 i}$ as colorless needles (1.85 g, 93\%).

(R)-3,3'-Bis(3,3-dimethylbutyl)-2,2'-dimethoxy-1,1'-binaphthyl (7) Colorless prisms.

Mp: $48.5-50.0{ }^{\circ} \mathrm{C}$.

TLC: $R_{f} 0.69$ (Hexane/EtOAc $=9 / 1$, stained white with anisaldehyde). $[\alpha]_{\mathrm{D}}{ }^{24}-85.2\left(c 1.01, \mathrm{CHCl}_{3}\right)$.

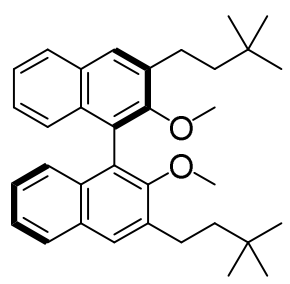

IR (ATR): 2951, 1235, 1012, 748, $674 \mathrm{~cm}^{-1}$. 
${ }^{1} \mathrm{H}$ NMR (400 MHz, $\left.\mathrm{CDCl}_{3}\right): \delta 1.02$ (s, 18H), 1.58-1.76 (m, 4H), 2.78-2.94 (m, 4H), 3.29 (s, 6H), 7.09-7.20 (m, 4H, ArH), 7.35 (t, $J=8.2 \mathrm{~Hz}, 2 \mathrm{H}, \mathrm{Ar} H), 7.79$ (s, 2H, ArH), 7.82 (d, $J=8.2$ $\mathrm{Hz}, 2 \mathrm{H}, \mathrm{Ar} H)$.

${ }^{13} \mathrm{C}$ NMR $\left(100 \mathrm{MHz}, \mathrm{CDCl}_{3}\right): \delta 26.0,29.4,30.7,45.0,60.7,124.5,124.6,125.3,125.7,127.2$, $128.5,130.8,133.0,136.9,155.5$.

MS (EI): $m / z 482\left(\mathrm{M}^{+}\right)$.

HRMS: Calcd for $\mathrm{C}_{34} \mathrm{H}_{42} \mathrm{O}_{2} 482.3185$, found 482.3161 .

\section{(R)-3,3'-Bis(3,3-dimethylbutyl)-2,2'-dihydroxy-1,1'-binaphthyl (3i)}

Colorless needles.

Mp: $76.0-78.0{ }^{\circ} \mathrm{C}$.

TLC: $R_{f} 0.72$ (Hexane/EtOAc $=4 / 1$, stained purple with anisaldehyde).

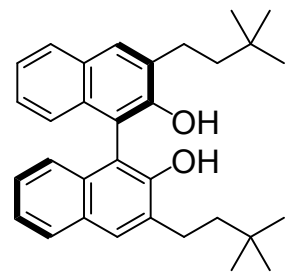
$[\alpha]_{\mathrm{D}}^{26}+47.6\left(c 1.00, \mathrm{CHCl}_{3}\right)$.

IR (ATR): 3523, 2951, 747, $653 \mathrm{~cm}^{-1}$.

${ }^{1} \mathrm{H}$ NMR (400 MHz, $\left.\mathrm{CDCl}_{3}\right): \delta 1.01$ (s, 18H), 1.62-1.68 (m, 4H), 2.81-2.88 (m, 4H), 5.12 (s, 2H, OH), 7.07 (d, $J=8.2 \mathrm{~Hz}, 2 \mathrm{H}, \mathrm{ArH}), 7.21-7.27$ (m, 2H, ArH), 7.31-7.36 (m, 2H, ArH), $7.80(\mathrm{~s}, 2 \mathrm{H}, \operatorname{Ar} H), 7.83(\mathrm{~d}, J=8.2 \mathrm{~Hz}, 2 \mathrm{H}, \operatorname{Ar} H)$.

${ }^{13} \mathrm{C}$ NMR (100 MHz, $\left.\mathrm{CDCl}_{3}\right): \delta 26.2,29.3,30.7,44.1,110.7,123.8,124.0,126.3,127.6$, $129.5,129.6,132.0,132.2,151.8$.

MS (EI): $m / z 455\left(\mathrm{M}+\mathrm{H}^{+}\right)$.

HRMS: Calcd for $\mathrm{C}_{32} \mathrm{H}_{38} \mathrm{O}_{2} 454.2872$, found 454.2875.

The enantiomeric excess was determined to be $>99 \%$ ee by chiral HPLC with Daicel Chiralpak AD-H column $(0.46 \mathrm{~cm} \varphi \times 25 \mathrm{~cm})$ [eluent: Hexane/IPA $=49 / 1$; flow rate: 1.0 $\mathrm{mL} / \mathrm{min}$; detection: $254 \mathrm{~nm}$; $\left.t_{\mathrm{R}}: 4.7 \mathrm{~min}(S), 6.3 \mathrm{~min}(R)\right]$. 
Typical Procedure for Asymmetric 1,2-Addition of Grignard Reagents (Table 1, Entry 10).
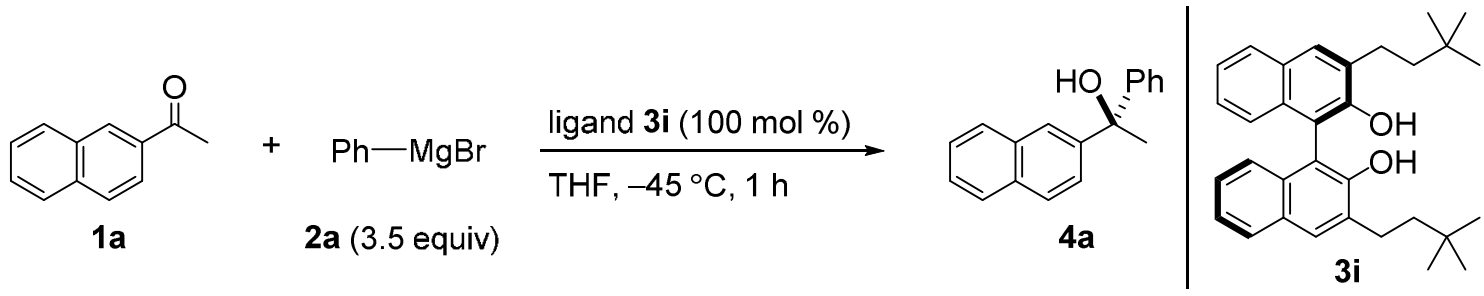

A solution of $\mathrm{Ph}-\mathrm{MgBr}(\mathbf{2 a})$ in $\mathrm{Et}_{2} \mathrm{O}(1.45 \mathrm{M}, 1.21 \mathrm{~mL}, 1.75 \mathrm{mmol}, 3.5$ equiv.) was added dropwise to the solution of ligand $3 \mathbf{i}$ (228 mg, $0.5 \mathrm{mmol}, 1.0$ equiv.) and 2'-acetonaphthone (1a) $(85.1 \mathrm{mg}, 0.5 \mathrm{mmol})$ in THF $(1.0 \mathrm{~mL})$ at $-45^{\circ} \mathrm{C}$. After the mixture was stirred for $1 \mathrm{~h}$, the reaction was quenched with sat. $\mathrm{NH}_{4} \mathrm{Cl}(3.0 \mathrm{~mL})$ and stirred for $0.5 \mathrm{~h}$. The aqueous layer was extracted with EtOAc $(3 \times 20 \mathrm{~mL})$ and the combined organic layers were washed with brine $(10 \mathrm{~mL})$, and dried over $\mathrm{Na}_{2} \mathrm{SO}_{4}$. After filtration and evaporation, the obtained crude product was purified by column chromatography (Hexane $/ \mathrm{CH}_{2} \mathrm{Cl}_{2}=1 / 1-1 / 2, \mathrm{SiO}_{2} 6 \mathrm{~g}$ ) to furnish the product $4 \mathbf{a}(117.0 \mathrm{mg}, 94 \%$ yield, 93\% ee). Ligand $\mathbf{3 i}$ could be easily recovered and reused. The quantitative amounts of ligand 3i was recovered after asymmetric 1,2addition. The $\mathrm{R}_{f}$ values of ligand $\mathbf{3 i}$ and product $4 \mathbf{a}$ were 0.74 and 0.15 , each other (hexane $/ \mathrm{CH}_{2} \mathrm{Cl}_{2}=1 / 1$ ). And the $\mathrm{R}_{f}$ values of all other products 4 were similar to $4 \mathrm{a}$.

\section{(R)-1-(2-Naphthalenyl)-1-phenylethanol (4a) ${ }^{4}$}

Colorless oil.

TLC: $R_{f} 0.49$ (Hexane/EtOAc $=4 / 1$, stained blue with anisaldehyde).

$[\alpha]_{\mathrm{D}}{ }^{17}+17.3\left(c 1.1, \mathrm{CH}_{2} \mathrm{Cl}_{2}\right)$ for $93 \%$ ee $(R) ;\left[\left(\right.\right.$ lit $^{4}:[\alpha]_{\mathrm{D}}{ }^{25}-16.1, c$ 1.0,

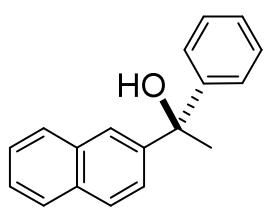

$\left.\mathrm{CH}_{2} \mathrm{Cl}_{2}\right)$ for $92 \%$ ee $(S)$.].

${ }^{1} \mathrm{H}$ NMR (400 MHz, $\left.\mathrm{CDCl}_{3}\right): \delta 2.06\left(\mathrm{~s}, 3 \mathrm{H}, \mathrm{CH}_{3}\right), 2.27(\mathrm{~s}, 1 \mathrm{H}, \mathrm{OH}), 7.23-7.28(\mathrm{~m}, 1 \mathrm{H}, \mathrm{Ar} H)$, 7.29-7.35 (m, 2H, ArH), 7.39-7.51 (m, 5H, ArH), 7.74-7.86 (m, 3H, ArH), 7.98 (s, 1H, ArH).

${ }^{13} \mathrm{C}$ NMR $\left(100 \mathrm{MHz}, \mathrm{CDCl}_{3}\right): \delta 30.7,76.3,123.7,124.9,125.9,126.1,127.0,127.5,127.9$, 128.2, 132.3, 132.9, 145.2, 147.7 (two carbons overlapped).

The enantiomeric excess was determined to be $93 \%$ ee by chiral HPLC with Daicel Chiralpak OJ column $(0.46 \mathrm{~cm} \varphi \times 25 \mathrm{~cm})$ [eluent: Hexane/IPA $=4 / 1$; flow rate: $1.0 \mathrm{~mL} / \mathrm{min}$; detection: $\left.254 \mathrm{~nm} ; t_{\mathrm{R}}: 15.6 \min (S), 19.5 \min (R)\right]$. 


\section{(S)-1-(2-Naphthalenyl)-1-phenylethanol (ent-4a) ${ }^{4}$}

$[\alpha]_{\mathrm{D}}{ }^{19}-13.4\left(c 1.14, \mathrm{CH}_{2} \mathrm{Cl}_{2}\right)$ for $94 \%$ ee $(S)$.

The enantiomeric excess was determined to be $94 \%$ ee by chiral HPLC with

Daicel Chiralpak OJ column $(0.46 \mathrm{~cm} \varphi \times 25 \mathrm{~cm})$ [eluent: Hexane/IPA $=$

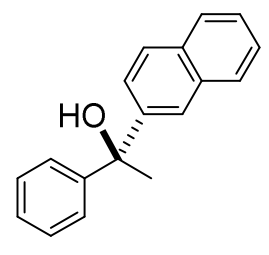

4/1; flow rate: $1.0 \mathrm{~mL} / \mathrm{min}$; detection: $254 \mathrm{~nm}$; $t_{\mathrm{R}}: 15.6 \min (S), 20.3 \min (R)$ ].

\section{(R)-1-(1-Naphthalenyl)-1-phenylethanol (4b) ${ }^{4}$}

Colorless oil.

TLC: $R_{f} 0.49$ (Hexane/EtOAc $=4 / 1$, stained blue with anisaldehyde).

$[\alpha]_{\mathrm{D}}{ }^{19}+87.3\left(c 0.97, \mathrm{CH}_{2} \mathrm{Cl}_{2}\right)$ for $96 \%$ ee $(R)$. [(lit ${ }^{4}:[\alpha]_{\mathrm{D}}{ }^{25}-95.4, c 0.94$,

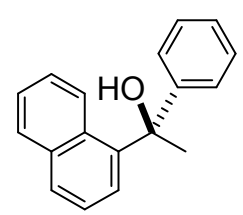

$\mathrm{CH}_{2} \mathrm{Cl}_{2}$ ) for $93 \%$ ee $(S)$.].

${ }^{1} \mathrm{H}$ NMR (400 MHz, $\left.\mathrm{CDCl}_{3}\right): \delta 2.08\left(\mathrm{~s}, 3 \mathrm{H}, \mathrm{CH}_{3}\right), 2.41(\mathrm{~s}, 1 \mathrm{H}, \mathrm{OH}), 7.17-7.30(\mathrm{~m}, 4 \mathrm{H}, \mathrm{Ar} H)$, 7.33-7.41 (m, 3H, ArH), 7.51 (t, $J=8.2 \mathrm{~Hz}, 1 \mathrm{H}, \operatorname{Ar} H), 7.78-7.93$ (m, 4H, ArH).

${ }^{13} \mathrm{C}$ NMR $\left(100 \mathrm{MHz}, \mathrm{CDCl}_{3}\right): \delta 32.8,77.1,124.0,124.6,125.2,125.4,126.7,127.2,128.3$, 128.7, 129.0, 130.6, 134.8, 141.9, 148.5 (one carbon overlapped).

The enantiomeric excess was determined to be $96 \%$ ee by chiral HPLC with Daicel Chiralpak OJ column $(0.46 \mathrm{~cm} \varphi \times 25 \mathrm{~cm})$ [eluent: Hexane/IPA $=9 / 1$; flow rate: $1.0 \mathrm{~mL} / \mathrm{min}$; detection: $\left.254 \mathrm{~nm} ; t_{\mathrm{R}}: 13.8 \min (S), 19.3 \min (R)\right]$.

\section{(R)-1-(4-Methoxyphenyl)-1-phenylethanol (4c) ${ }^{4}$}

Colorless oil.

TLC: $R_{f} 0.34$ (Hexane/EtOAc $=4 / 1$, stained purple with anisaldehyde).

$[\alpha]_{\mathrm{D}}{ }^{19}+21.6\left(c 0.75, \mathrm{CH}_{2} \mathrm{Cl}_{2}\right)$ for $91 \%$ ee $(R) .\left[\left(\mathrm{lit}^{4}:[\alpha]_{\mathrm{D}}{ }^{25}-14.6(c 0.71\right.\right.$,

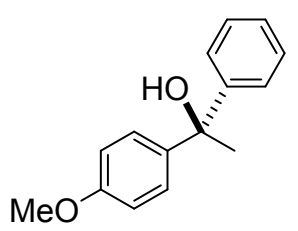
$\mathrm{CH}_{2} \mathrm{Cl}_{2}$ ) for $90 \%$ ee $(S)$.].

${ }^{1} \mathrm{H}$ NMR (400 MHz, $\mathrm{CDCl}_{3}$ ): $\delta 1.93\left(\mathrm{~s}, 3 \mathrm{H}, \mathrm{CH}_{3}\right), 2.12$ (s, 1H, OH), 3.79 (s, 3H, OMe), 6.84 (d, $J=8.7 \mathrm{~Hz}, 2 \mathrm{H}, \operatorname{Ar} H), 7.21-7.27$ (m, 1H, ArH), 7.29-7.35 (m, 4H, ArH), 7.41 (d, $J=7.8 \mathrm{~Hz}$, $2 \mathrm{H}, \operatorname{Ar} H)$.

${ }^{13} \mathrm{C}$ NMR $\left(100 \mathrm{MHz}, \mathrm{CDCl}_{3}\right): \delta 30.9,55.2,75.9,113.4,125.7,126.8,127.1,128.1,140.2$, 148.2, 158.4.

The enantiomeric excess was determined to be $91 \%$ ee by chiral HPLC with Daicel Chiralpak OJ column $(0.46 \mathrm{~cm} \varphi \times 25 \mathrm{~cm})$ [eluent: Hexane/IPA $=4 / 1$; flow rate: $1.0 \mathrm{~mL} / \mathrm{min}$; detection: $\left.254 \mathrm{~nm} ; t_{\mathrm{R}}: 18.9 \min (R), 24.0 \min (S)\right]$. 
(S)-1-(4-Methoxyphenyl)-1-phenylethanol (ent-4c) ${ }^{4}$

$[\alpha]_{\mathrm{D}}{ }^{20}-14.1\left(c 0.76, \mathrm{CH}_{2} \mathrm{Cl}_{2}\right)$ for $84 \%$ ee $(S)$.

The enantiomeric excess was determined to be $84 \%$ ee by chiral HPLC with Daicel Chiralpak OJ column $(0.46 \mathrm{~cm} \varphi \times 25 \mathrm{~cm})$ [eluent: Hexane/IPA $=$

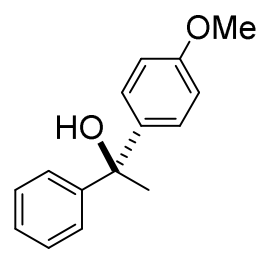

4/1; flow rate: $1.0 \mathrm{~mL} / \mathrm{min}$; detection: $254 \mathrm{~nm}$; $t_{\mathrm{R}}: 20.0 \mathrm{~min}(R), 24.2 \mathrm{~min}(S)$ ].

(R)-1-(4-Bromophenyl)-1-phenylethanol (4d) ${ }^{5}$

Colorless oil.

TLC: $R_{f} 0.47$ (Hexane/EtOAc $=4 / 1$, stained purple with anisaldehyde).

$[\alpha]_{\mathrm{D}}^{18}-6.67\left(c\right.$ 2.16, $\left.\mathrm{CH}_{2} \mathrm{Cl}_{2}\right)$ for $91 \%$ ee $(R)$. $\left[\left(\mathrm{lit}^{5}:[\alpha]_{\mathrm{D}}+9.96, c\right.\right.$ 2.0,

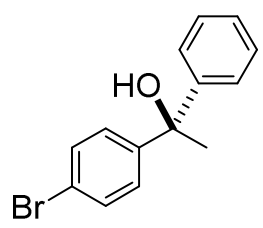

$\mathrm{CH}_{2} \mathrm{Cl}_{2}$ ) for $>99 \%$ ee $(S)$.].

${ }^{1} \mathrm{H}$ NMR (400 MHz, $\left.\mathrm{CDCl}_{3}\right): \delta 1.93\left(\mathrm{~s}, 3 \mathrm{H}, \mathrm{CH}_{3}\right), 2.15(\mathrm{~s}, 1 \mathrm{H}, \mathrm{OH}), 7.23-7.36(\mathrm{~m}, 5 \mathrm{H}, \mathrm{Ar} H)$, 7.37-7.46 (m, 4H, ArH).

${ }^{13} \mathrm{C}$ NMR (100 MHz, $\left.\mathrm{CDCl}_{3}\right): \delta 30.7,75.9,120.9,125.7,127.2,127.7,128.3,131.2,147.1$, 147.3

The enantiomeric excess was determined to be $91 \%$ ee by chiral HPLC with Daicel Chiralpak OD-H column $(0.46 \mathrm{~cm} \varphi \times 25 \mathrm{~cm})$ [eluent: Hexane/IPA $=99 / 1$; flow rate: $1.0 \mathrm{~mL} / \mathrm{min}$; detection: $\left.254 \mathrm{~nm} ; t_{\mathrm{R}}: 43.8 \min (S), 46.6 \min (R)\right]$.

\section{(R)-1-(4-Chlorophenyl)-1-phenylethanol (4e $)^{5}$}

Colorless oil.

TLC: $R_{f} 0.51$ (Hexane/EtOAc $=4 / 1$, stained purple with anisaldehyde).

$[\alpha]_{\mathrm{D}}^{18}-9.25\left(c 1.01, \mathrm{CHCl}_{3}\right)$ for $86 \%$ ee $(R)$. $\left[\left(\mathrm{lit}^{6}:[\alpha]_{\mathrm{D}}{ }^{22}-11.2, c 1.9\right.\right.$,

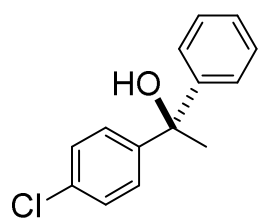
$\mathrm{CHCl}_{3}$ ) for $92 \%$ ee $(R)$.].

${ }^{1} \mathrm{H}$ NMR (400 MHz, $\left.\mathrm{CDCl}_{3}\right): \delta 1.94\left(\mathrm{~s}, 3 \mathrm{H}, \mathrm{CH}_{3}\right), 2.17(\mathrm{~s}, 1 \mathrm{H}, \mathrm{OH}), 7.23-7.42(\mathrm{~m}, 9 \mathrm{H}, \mathrm{Ar} H)$.

${ }^{13} \mathrm{C}$ NMR (100 MHz, $\mathrm{CDCl}_{3}$ ): $\delta 30.8,75.8,125.7,127.3,128.3,132.7,146.5,147.4$ (two carbons overlapped).

The enantiomeric excess was determined to be $86 \%$ ee by chiral HPLC with Daicel Chiralpak AD-H column $(0.46 \mathrm{~cm} \varphi \times 25 \mathrm{~cm})$ [eluent: Hexane/IPA $=99 / 1$; flow rate: $1.0 \mathrm{~mL} / \mathrm{min}$; detection: $\left.254 \mathrm{~nm} ; t_{\mathrm{R}}: 37.1 \mathrm{~min}(R), 41.3 \mathrm{~min}(S)\right]$. 
(S)-1-(4-Chlorophenyl)-1-phenylethanol (ent-4e) $)^{5}$

$[\alpha]_{\mathrm{D}}{ }^{24}+11.9\left(c 1.05, \mathrm{CHCl}_{3}\right)$ for $97 \%$ ee $(S)$.

The enantiomeric excess was determined to be $97 \%$ ee by chiral HPLC with

Daicel Chiralpak AD-H column $(0.46 \mathrm{~cm} \varphi \times 25 \mathrm{~cm})$ [eluent: Hexane/IPA $=$

99/1; flow rate: $1.0 \mathrm{~mL} / \mathrm{min}$; detection: $254 \mathrm{~nm}$; $t_{\mathrm{R}}: 37.1 \mathrm{~min}(R), 40.5 \mathrm{~min}(S)$ ].

\section{(R)-1-(2-Naphthalenyl)-1-phenylpropanol (4f) ${ }^{7}$}

Colorless oil.

TLC: $R_{f} 0.52$ (Hexane/EtOAc $=4 / 1$, stained purple with anisaldehyde).

$[\alpha]_{\mathrm{D}}{ }^{27}-1.97\left(c 1.07, \mathrm{CH}_{2} \mathrm{Cl}_{2}\right)$ for $86 \%$ ee $(R) ;\left[\left(\mathrm{lit}^{7}:[\alpha]_{\mathrm{D}}{ }^{20}+2.5, c 4.9\right.\right.$,

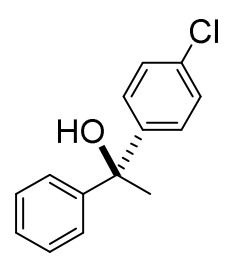

$\mathrm{CH}_{2} \mathrm{Cl}_{2}$ ) for $86 \%$ ee $(S)$.].

IR (ATR): $3460 \mathrm{~cm}^{-1}$.

${ }^{1} \mathrm{H}$ NMR (400 MHz, $\left.\mathrm{CDCl}_{3}\right): \delta 0.92\left(\mathrm{t}, J=7.3 \mathrm{~Hz}, 3 \mathrm{H}, \mathrm{CH}_{2} \mathrm{CH}_{3}\right), 2.16(\mathrm{~s}, 1 \mathrm{H}, \mathrm{OH}), 2.44$ (q, $J$ $\left.=7.3 \mathrm{~Hz}, 2 \mathrm{H}, \mathrm{CH}_{2} \mathrm{CH}_{3}\right), 7.23(\mathrm{t}, J=7.8 \mathrm{~Hz}, 1 \mathrm{H}, \mathrm{ArH}), 7.31(\mathrm{t}, J=8.2 \mathrm{~Hz}, 2 \mathrm{H}, \mathrm{ArH}), 7.38-$ 7.50 (m, 5H, ArH), 7.75 (d, $J=8.7 \mathrm{~Hz}, 1 \mathrm{H}, \operatorname{Ar} H), 7.79$ (d, $J=9.2 \mathrm{~Hz}, 1 \mathrm{H}, \operatorname{Ar} H), 7.84$ (d, $J=$ $9.2 \mathrm{~Hz}, 1 \mathrm{H}, \operatorname{Ar} H), 7.99$ (s, 1H, $\operatorname{Ar} H)$.

${ }^{13} \mathrm{C}$ NMR $\left(100 \mathrm{MHz}, \mathrm{CDCl}_{3}\right): \delta 8.14,34.2,78.5,124.2,125.0,125.8,126.0,126.2,126.9$, $127.4,127.8,128.1,128.2,132.2,133.0,144.1,146.7$.

MS (EI): $m / z 262\left(\mathrm{M}^{+}\right)$.

HRMS: Calcd for $\mathrm{C}_{19} \mathrm{H}_{18} \mathrm{O}_{1} 262.1358$, found 262.1334.

The enantiomeric excess was determined to be $86 \%$ ee by chiral HPLC with Daicel Chiralpak OJ column $(0.46 \mathrm{~cm} \varphi \times 25 \mathrm{~cm})$ [eluent: Hexane/IPA $=4 / 1$; flow rate: $1.0 \mathrm{~mL} / \mathrm{min}$; detection: $\left.254 \mathrm{~nm} ; t_{\mathrm{R}}: 12.2 \min (S), 15.6 \min (R)\right]$.

\section{(S)-1-Cyclohexyl-1-phenylethanol (4g) ${ }^{4}$}

Colorless oil.

TLC: $R_{f} 0.57$ (Hexane/EtOAc $=4 / 1$, stained purple with anisaldehyde).

$[\alpha]_{\mathrm{D}}{ }^{26}-5.39\left(c 0.94, \mathrm{CH}_{2} \mathrm{Cl}_{2}\right)$ for $30 \%$ ee $(S) ;\left[\left(\mathrm{lit}^{4}:[\alpha]_{\mathrm{D}}{ }^{25}+18.2, c 0.72\right.\right.$,

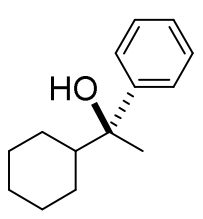
$\mathrm{CH}_{2} \mathrm{Cl}_{2}$ ) for $81 \%$ ee $(R)$.].

${ }^{1} \mathrm{H}$ NMR (400 MHz, $\left.\mathrm{CDCl}_{3}\right): \delta$ 0.91-1.26 (m, 5H), 1.51-1.79 (m, 10H), $7.23(\mathrm{t}, J=7.3 \mathrm{~Hz}, 1 \mathrm{H}$, $\operatorname{Ar} H), 7.33$ (t, $J=7.3 \mathrm{~Hz}, 2 \mathrm{H}, \operatorname{Ar} H), 7.40$ (d, $J=7.3 \mathrm{~Hz}, 2 \mathrm{H}, \operatorname{Ar} H)$.

${ }^{13} \mathrm{C}$ NMR (100 MHz, $\left.\mathrm{CDCl}_{3}\right): \delta 26.3,26.6,26.7,27.1,27.3,48.9,76.6,125.3,126.3,127.8$, 147.8 (one carbon overlapped). 
The enantiomeric excess was determined to be $30 \%$ ee by chiral HPLC with Daicel Chiralpak OJ column $(0.46 \mathrm{~cm} \varphi \times 25 \mathrm{~cm})$ [eluent: Hexane/IPA $=99 / 1$; flow rate: $1.0 \mathrm{~mL} / \mathrm{min}$; detection: $\left.254 \mathrm{~nm} ; t_{\mathrm{R}}: 10.1 \min (R), 12.1 \min (S)\right]$.

\section{(R)-1-Cyclohexyl-1-phenylethanol (ent-4g) ${ }^{4}$}

$[\alpha]_{\mathrm{D}}{ }^{28}+9.14\left(c 0.9, \mathrm{CH}_{2} \mathrm{Cl}_{2}\right)$ for $59 \%$ ee $(R)$.

The enantiomeric excess was determined to be $59 \%$ ee by chiral HPLC with

Daicel Chiralpak OJ column $(0.46 \mathrm{~cm} \varphi \times 25 \mathrm{~cm})$ [eluent: Hexane/IPA = 99/1;

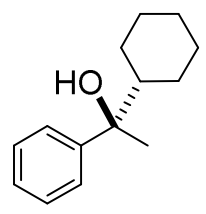

flow rate: $1.0 \mathrm{~mL} / \mathrm{min}$; detection: $\left.254 \mathrm{~nm} ; t_{\mathrm{R}}: 10.0 \mathrm{~min}(R), 12.6 \mathrm{~min}(S)\right]$.

\section{(S)-1-(3-Methoxyphenyl)-1-phenylethanol (4h) ${ }^{4}$}

Yellow oil.

TLC: $R_{f} 0.43$ (Hexane/EtOAc $=4 / 1$, stained purple with anisaldehyde).

$[\alpha]_{\mathrm{D}}{ }^{28}+9.25\left(c 2.57, \mathrm{CH}_{2} \mathrm{Cl}_{2}\right)$ for $87 \%$ ee $(S) \cdot\left[\left(\mathrm{lit}^{4}:[\alpha]_{\mathrm{D}}{ }^{25}+9.17\right.\right.$ (c 3.0,

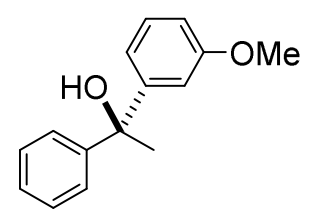

$\mathrm{CH}_{2} \mathrm{Cl}_{2}$ ) for $92 \%$ ee $(S)$.].

${ }^{1} \mathrm{H}$ NMR (400 MHz, $\mathrm{CDCl}_{3}$ ): $\delta 1.95$ (s, 3H, $\mathrm{CH}_{3}$ ), 2.18 (s, 1H, OH), 3.78 (s, 3H, OMe), 6.78 (dd, $J=2.7,8.2 \mathrm{~Hz}, 1 \mathrm{H}, \operatorname{Ar} H), 6.95-6.98(\mathrm{~m}, 1 \mathrm{H}, \operatorname{Ar} H), 7.01-7.03(\mathrm{~m}, 1 \mathrm{H}, \operatorname{Ar} H), 7.21-7.26$ (m, 2H, $\operatorname{Ar} H$ ), 7.29-7.35 (m, 2H, ArH), 7.40-7.44 (m, 2H, ArH).

${ }^{13} \mathrm{C}$ NMR $\left(100 \mathrm{MHz}, \mathrm{CDCl}_{3}\right): \delta 30.7,55.1,76.1,111.89,111.92,118.3,125.7,126.9,128.1$, 129.1, 147.7, 149.7, 159.3.

The enantiomeric excess was determined to be $87 \%$ ee by chiral HPLC with Daicel Chiralpak OD-H column $(0.46 \mathrm{~cm} \varphi \times 25 \mathrm{~cm})$ [eluent: Hexane/IPA $=49 / 1$; flow rate: $1.0 \mathrm{~mL} / \mathrm{min}$; detection: $\left.254 \mathrm{~nm} ; t_{\mathrm{R}}: 33.3 \min (S), 39.5 \min (R)\right]$.

\section{(S)-1-(2-Methoxyphenyl)-1-phenylethanol (4i) ${ }^{4}$}

Colorless prisms.

Mp: $69.5-71.0{ }^{\circ} \mathrm{C}$ for $6 \%$ ee $(S)$.

TLC: $R_{f} 0.50$ (Hexane/EtOAc $=4 / 1$, stained purple with anisaldehyde).

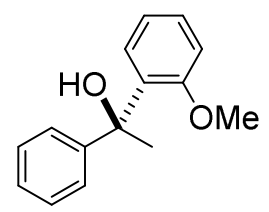

$[\alpha]_{\mathrm{D}}{ }^{29}-4.46\left(c 1.85, \mathrm{CH}_{2} \mathrm{Cl}_{2}\right)$ for $6 \%$ ee $(S)$. $\left[\left(\mathrm{lit}^{8}:[\alpha]_{\mathrm{D}}{ }^{23}+78.0\left(c 4.8, \mathrm{CH}_{2} \mathrm{Cl}_{2}\right)\right.\right.$ for $99 \%$ ee $(R)$.].

${ }^{1} \mathrm{H}$ NMR (400 MHz, $\mathrm{CDCl}_{3}$ ): $\delta 1.84$ (s, 3H, CH3), 3.59 (s, 3H, OMe), 4.67 (d, $J=1.4 \mathrm{~Hz}, 1 \mathrm{H}$, $\mathrm{OH}), 6.89(\mathrm{dd}, J=0.9,8.2 \mathrm{~Hz}, 1 \mathrm{H}, \operatorname{Ar} H), 7.03(\mathrm{dd}, J=0.9,7.4 \mathrm{~Hz}, 1 \mathrm{H}, \operatorname{Ar} H), 7.16-7.21$ (m, $1 \mathrm{H}, \operatorname{Ar} H), 7.22-7.33(\mathrm{~m}, 5 \mathrm{H}, \operatorname{Ar} H), 7.44$ (dd, $J=1.4,7.4 \mathrm{~Hz}, 1 \mathrm{H}, \operatorname{Ar} H)$. 
${ }^{13} \mathrm{C}$ NMR $\left(100 \mathrm{MHz}, \mathrm{CDCl}_{3}\right): \delta 30.1,55.5,76.2,112.1,120.8,124.7,126.2,126.9,127.6$, 128.7, 135.1, 149.5, 156.9.

The enantiomeric excess was determined to be $6 \%$ ee by chiral HPLC with Daicel Chiralpak OJ column $(0.46 \mathrm{~cm} \varphi \times 25 \mathrm{~cm})$ [eluent: Hexane/IPA = 4/1; flow rate: $1.0 \mathrm{~mL} / \mathrm{min}$; detection: $\left.254 \mathrm{~nm} ; t_{\mathrm{R}}: 7.0 \min (S), 22.0 \min (R)\right]$.

\section{(S)-1-(4-Methylphenyl)-1-phenylethanol $(4 \mathbf{j})^{5}$}

Colorless oil.

TLC: $R_{f} 0.47$ (Hexane/EtOAc $=4 / 1$, stained purple with anisaldehyde).

$[\alpha]_{\mathrm{D}}{ }^{29}-8.64\left(c 1.30, \mathrm{CH}_{2} \mathrm{Cl}_{2}\right)$ for $88 \%$ ee $(S) .\left[\left(\mathrm{lit}^{5}:[\alpha]_{\mathrm{D}}+16.0\left(c 1.20, \mathrm{CH}_{2} \mathrm{Cl}_{2}\right)\right.\right.$

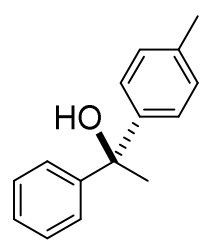
for $96 \%$ ee $(R)$.$] .$

${ }^{1} \mathrm{H} \mathrm{NMR}\left(400 \mathrm{MHz}, \mathrm{CDCl}_{3}\right): \delta 1.94$ (s, 3H), 2.14 (s, 1H, OH), 2.33 (s, 3H, $\left.\mathrm{ArCH}_{3}\right), 7.13$ (d, $J$ $=7.8 \mathrm{~Hz}, 2 \mathrm{H}, \mathrm{Ar} H), 7.20-7.34(\mathrm{~m}, 5 \mathrm{H}, \mathrm{Ar} H), 7.41(\mathrm{~d}, J=7.8 \mathrm{~Hz}, 2 \mathrm{H}, \mathrm{Ar} H)$.

${ }^{13} \mathrm{C}$ NMR $\left(100 \mathrm{MHz}, \mathrm{CDCl}_{3}\right): \delta 20.9,30.8,76.0,125.7,126.8,128.1,128.8,136.5,145.1$, 148.1 (one carbon overlapped).

The enantiomeric excess was determined to be $88 \%$ ee by chiral HPLC with Daicel Chiralpak AD-H column $(0.46 \mathrm{~cm} \varphi \times 25 \mathrm{~cm})$ [eluent: Hexane/IPA $=97 / 3$; flow rate: $1.0 \mathrm{~mL} / \mathrm{min}$; detection: $\left.254 \mathrm{~nm} ; t_{\mathrm{R}}: 16.3 \min (R), 17.1 \mathrm{~min}(S)\right]$.

\section{(S)-1-(2-Methylphenyl)-1-phenylethanol (4k) ${ }^{4}$}

Colorless oil.

TLC: $R_{f} 0.54$ (Hexane/EtOAc $=4 / 1$, stained purple with anisaldehyde).

$[\alpha]_{\mathrm{D}}{ }^{26}-51.1\left(c 2.13, \mathrm{CH}_{2} \mathrm{Cl}_{2}\right)$ for $90 \%$ ee $(S)$. [(lit ${ }^{4}:[\alpha]_{\mathrm{D}}{ }^{25}-60.3\left(c 1.8, \mathrm{CH}_{2} \mathrm{Cl}_{2}\right)$

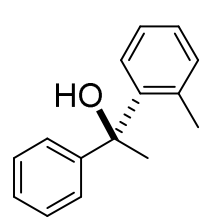
for $96 \%$ ee $(S)$.].

${ }^{1} \mathrm{H}$ NMR (400 MHz, $\mathrm{CDCl}_{3}$ ): $\delta 1.93$ (s, 3H), 1.98 (s, 3H), 2.12 (s, 1H, OH), 7.09-7.14 (m, 1H, $\operatorname{Ar} H)$, 7.19-7.34 (m, 7H, ArH), 7.67-7.72 (m, 1H, ArH).

${ }^{13} \mathrm{C}$ NMR (100 MHz, $\left.\mathrm{CDCl}_{3}\right): \delta 21.3,32.1,76.7,125.2,125.3,125.9,126.5,127.6,128.1$, 132.4, 137.1, 144.5, 147.9.

The enantiomeric excess was determined to be $90 \%$ ee by chiral HPLC with Daicel Chiralpak OJ column $(0.46 \mathrm{~cm} \varphi \times 25 \mathrm{~cm})$ [eluent: Hexane/IPA $=19 / 1$; flow rate: $1.0 \mathrm{~mL} / \mathrm{min}$; detection: $\left.254 \mathrm{~nm} ; t_{\mathrm{R}}: 12.5 \min (S), 18.7 \min (R)\right]$. 


\section{(S)-1-(4-Fluorophenyl)-1-phenylethanol (4I)}

Colorless oil.

TLC: $R_{f} 0.49$ (Hexane/EtOAc $=4 / 1$, stained purple with anisaldehyde).

$[\alpha]_{\mathrm{D}}^{28}+6.01\left(c 1.09, \mathrm{CHCl}_{3}\right)$ for $94 \%$ ee $(S) \cdot\left[\left(\mathrm{lit}^{5}:[\alpha]_{\mathrm{D}}-4.9\left(c 1.06, \mathrm{CHCl}_{3}\right)\right.\right.$

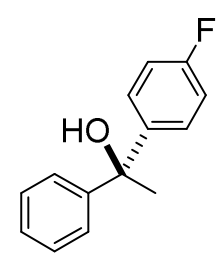
for $84 \%$ ee $(R)$.].

${ }^{1} \mathrm{H}$ NMR (400 MHz, $\left.\mathrm{CDCl}_{3}\right) \delta: 1.94\left(\mathrm{~s}, 3 \mathrm{H}, \mathrm{CH}_{3}\right), 2.15$ (s, $\left.1 \mathrm{H}, \mathrm{OH}\right), 6.99$ (t, J=8.7 Hz, 2H, $\operatorname{Ar} H)$, 7.22-7.28 (m, 1H, $\operatorname{Ar} H)$, 7.29-7.44 (m, 6H, $\operatorname{Ar} H)$.

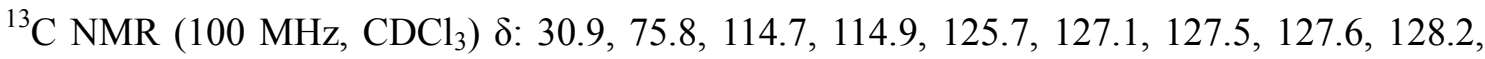
$143.77,143.8,147.7,160.4,162.9$.

The enantiomeric excess was determined to be $94 \%$ ee by chiral HPLC with Daicel Chiralpak AD-H column $(0.46 \mathrm{~cm} \varphi \times 25 \mathrm{~cm})$ [eluent: Hexane/IPA $=99 / 1$; flow rate: $0.8 \mathrm{~mL} / \mathrm{min}$; detection: $\left.254 \mathrm{~nm} ; t_{\mathrm{R}}: 40.7 \mathrm{~min}(R), 42.0 \mathrm{~min}(S)\right]$. 


\section{Investigation of Nonlinear Effect}

Table S1. Asymmetric 1,2-addition in the presence of various ee values of ligand $3 \mathbf{3 i}^{2}$<smiles>CC(=O)c1ccc2ccccc2c1</smiles>

1a

enry

1

2

3

4
$+\mathrm{Ph}-\mathrm{MgBr}$

2a (3.5 equiv)

$$
\underset{\text { THF, }-45^{\circ} \mathrm{C}, 1 \mathrm{~h}}{\stackrel{\text { ligand } 3 \mathbf{i}(100 \mathrm{~mol} \%)}{\longrightarrow}}
$$

(1)

yield of $4 a(\%) c$

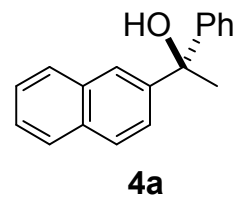

ee of $4 a(\%)^{b}$

94

93

94

55

95

41

95

19

${ }^{a}$ All reactions were conducted under the typical procedure.

${ }^{b}$ Enantiomeric excesses of ligand $\mathbf{3} \mathbf{i}$ and product $\mathbf{4 a}$ were detrermined by HPLC.

clsolated yield.

Figure S1. Relationship between the ee values of the ligand $3 \mathbf{i}$ and that of the product $4 \mathbf{a}$.

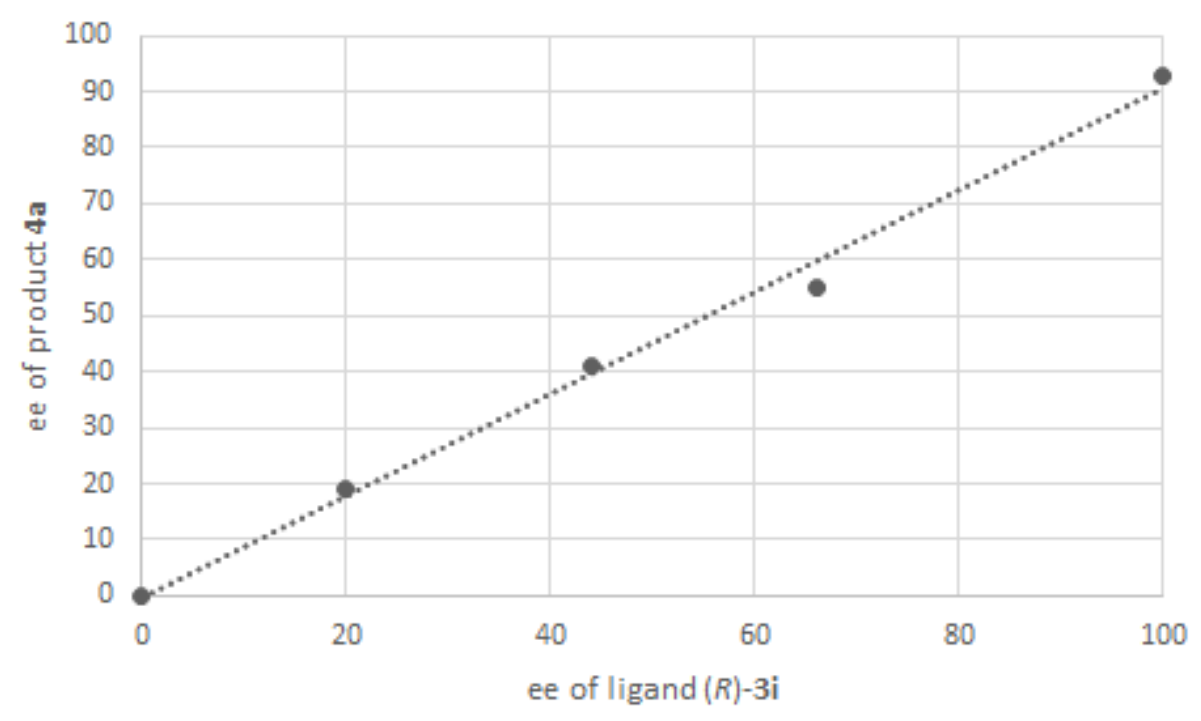


$\underline{{ }^{1} H \text { and }{ }^{13} C N M R \text { Spectra of New Compounds }}$

(R)-3,3'-Dibenzyl-2,2'-dihydroxy-1,1'-binaphthyl (3d)
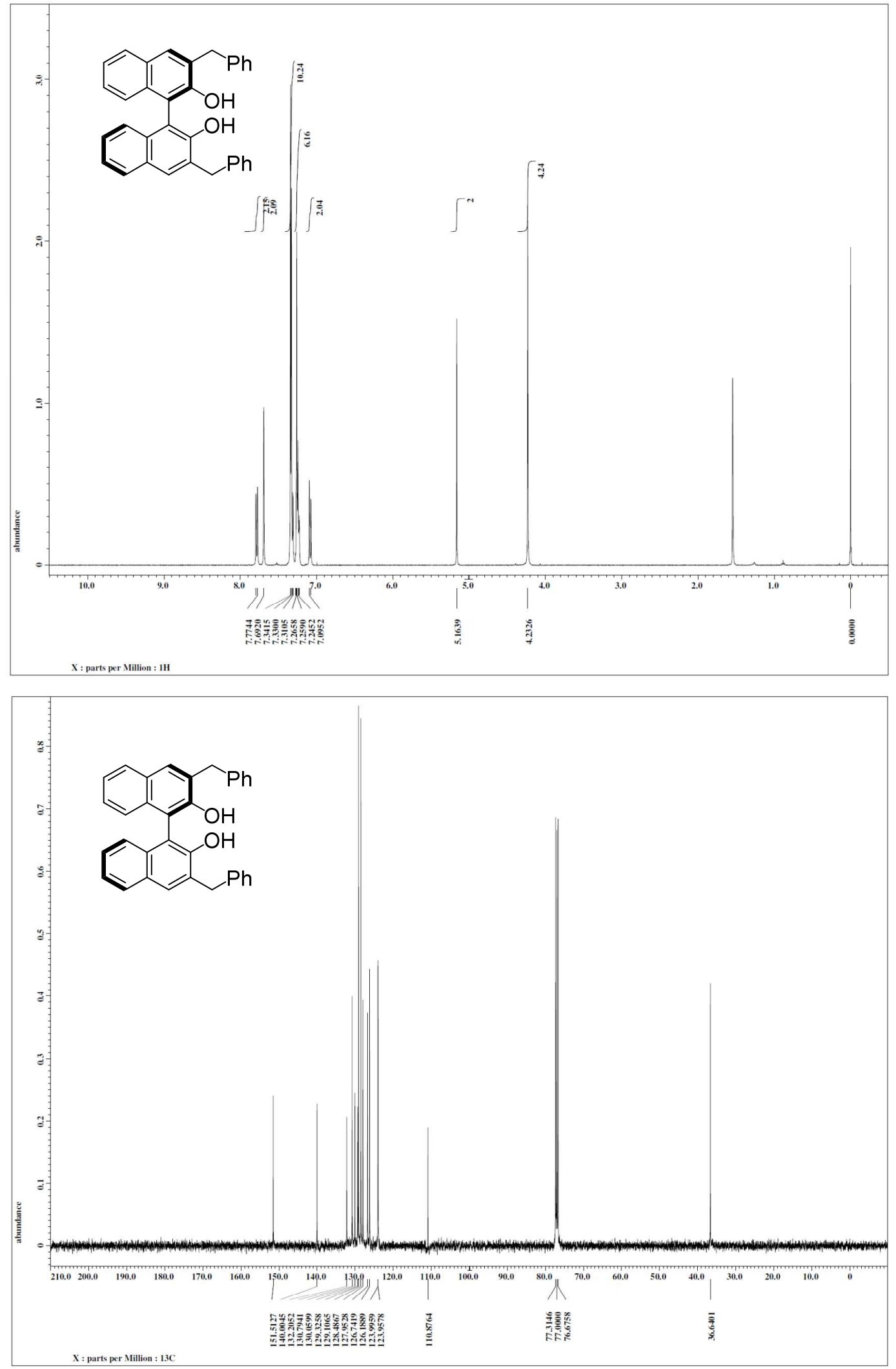
(R)-3,3'-Bis(1-methoxy-1-methylethyl)-2,2'-dihydroxy-1,1'-binaphthyl (3e)
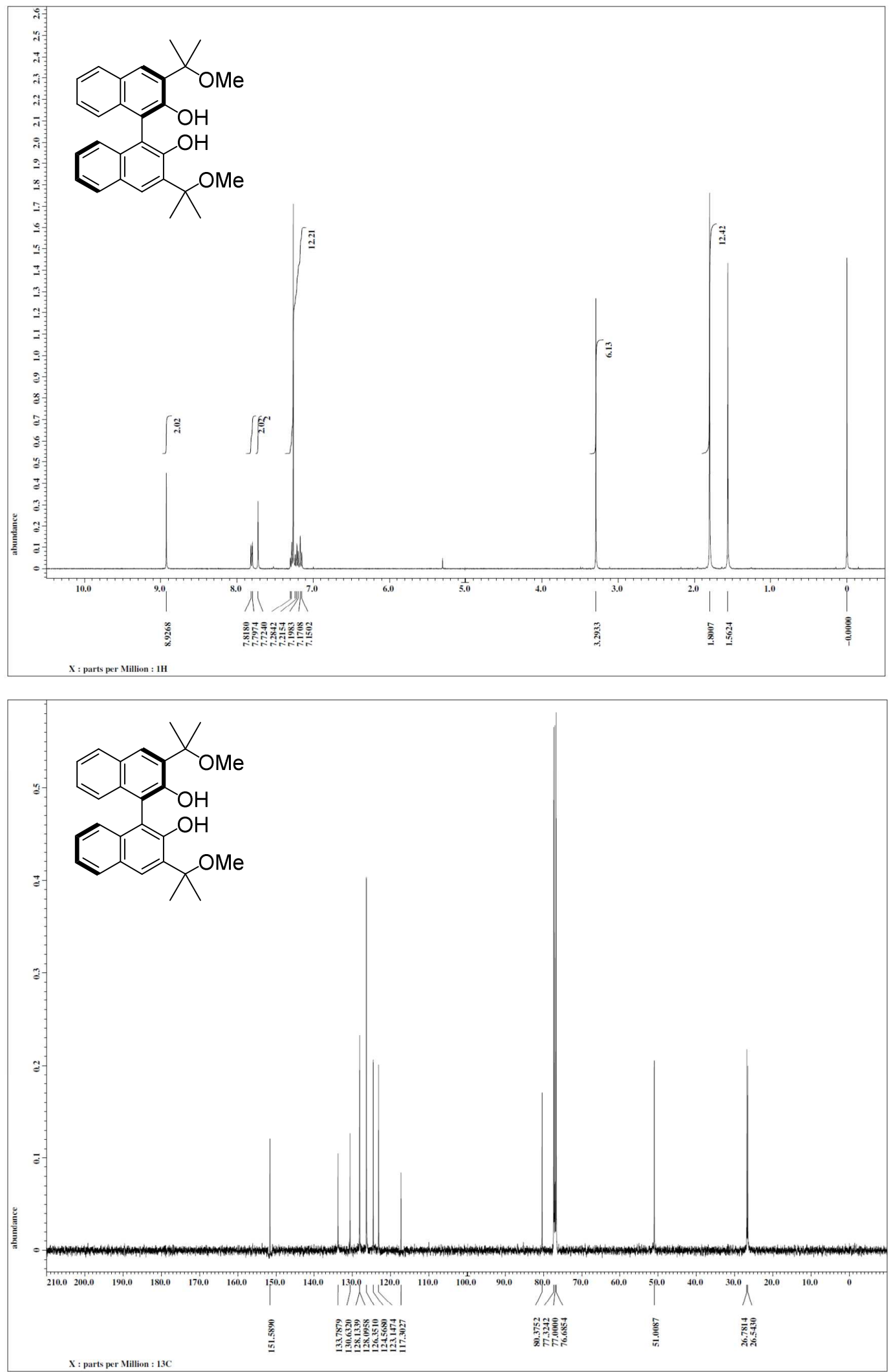
(R)-3,3'-Bis(2-methoxy-2-methylpropyl)-2,2'-dihydroxy-1,1'-binaphthyl (3f)
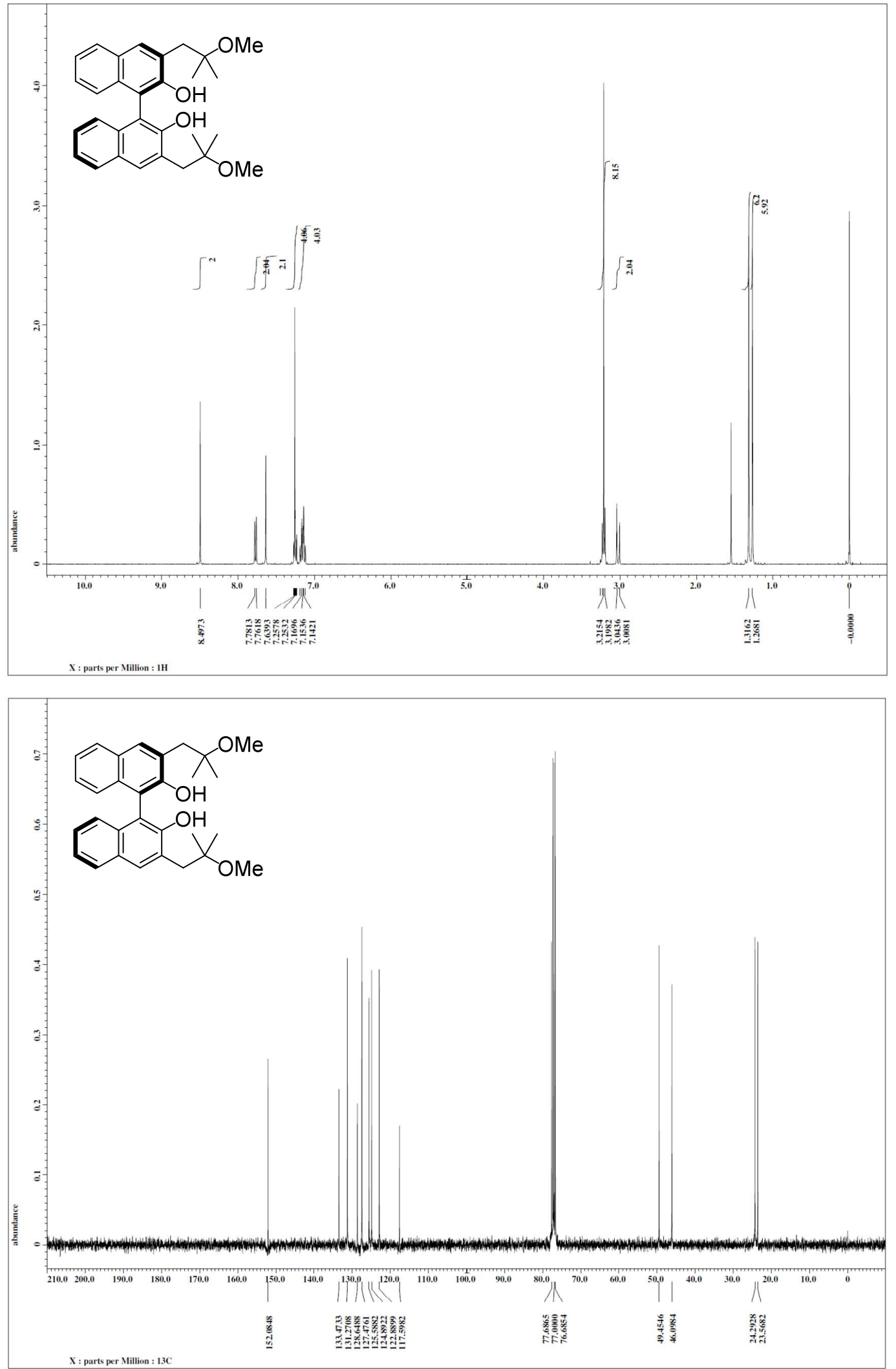
(R)-3,3'-Bis(2-ethoxy-2-methylpropyl)-2,2'-dihydroxy-1,1'-binaphtyl (3g)
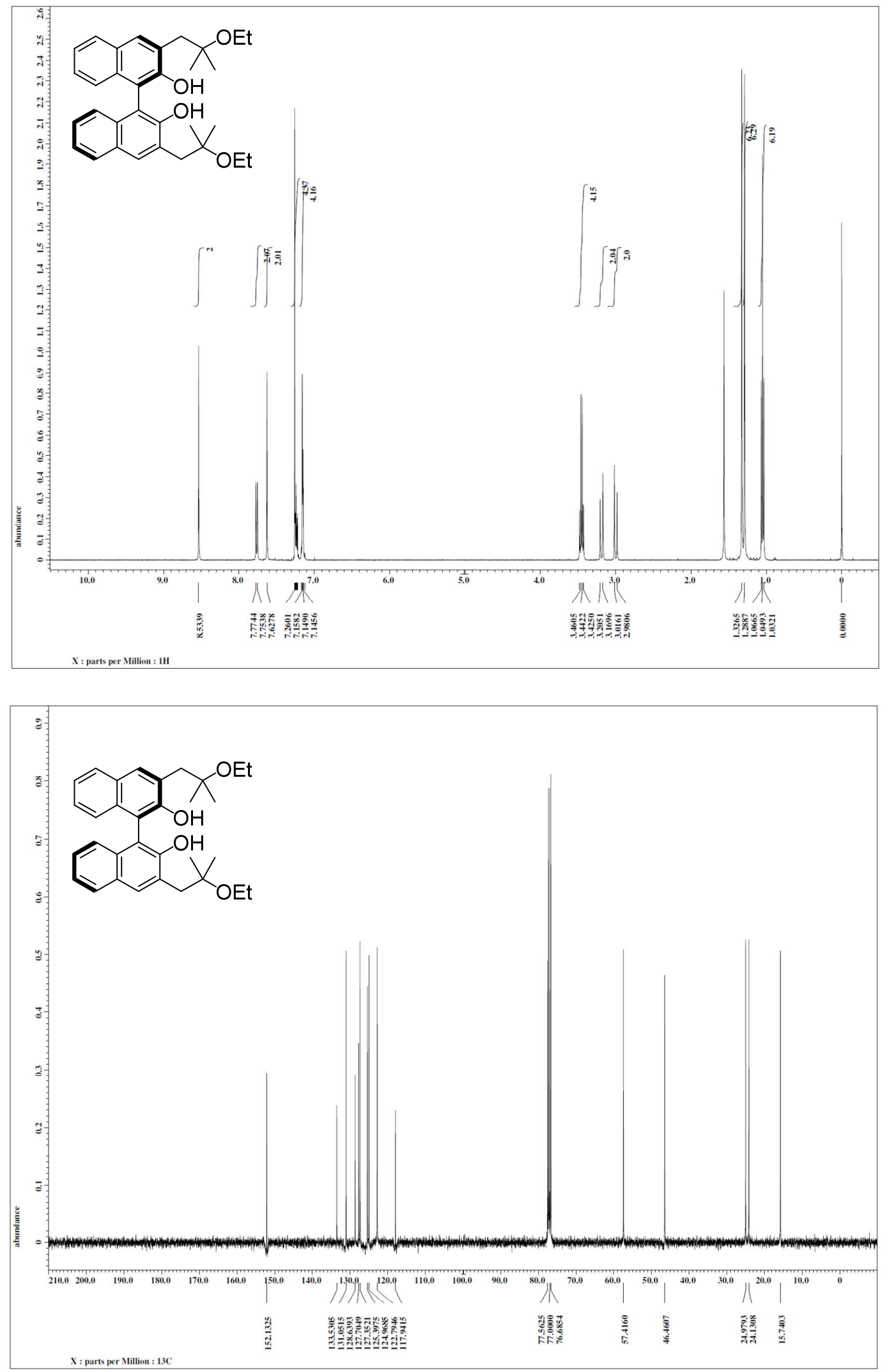
(R)-3,3'-Bis(2,2-dimethylpropyl)-2,2'-dihydroxy-1,1'-binaphthyl (3h)
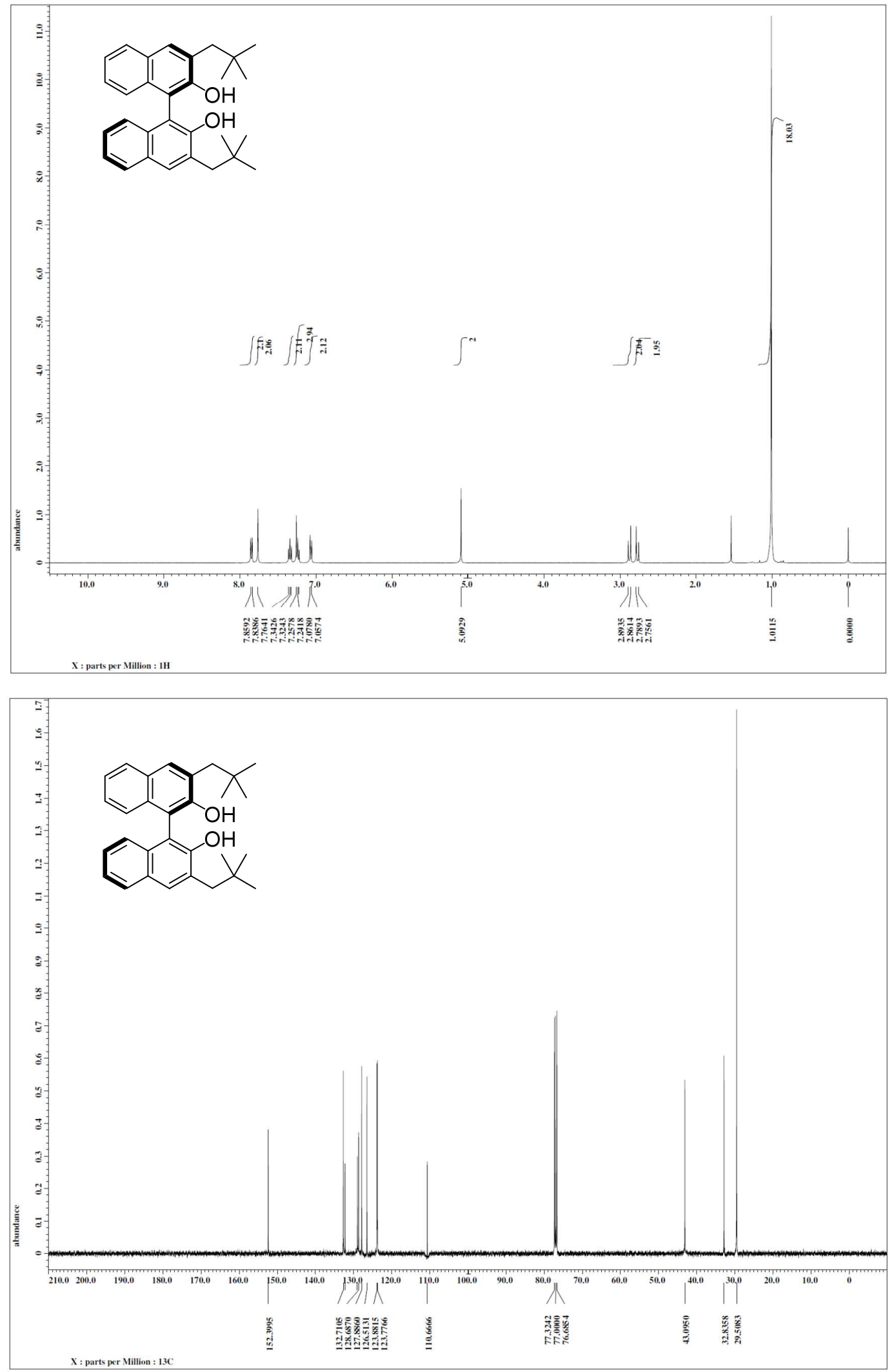
(R)-3,3'-Bis(3,3-dimethylbutyl)-2,2'-dimethoxy-1,1'-binaphthyl (7)
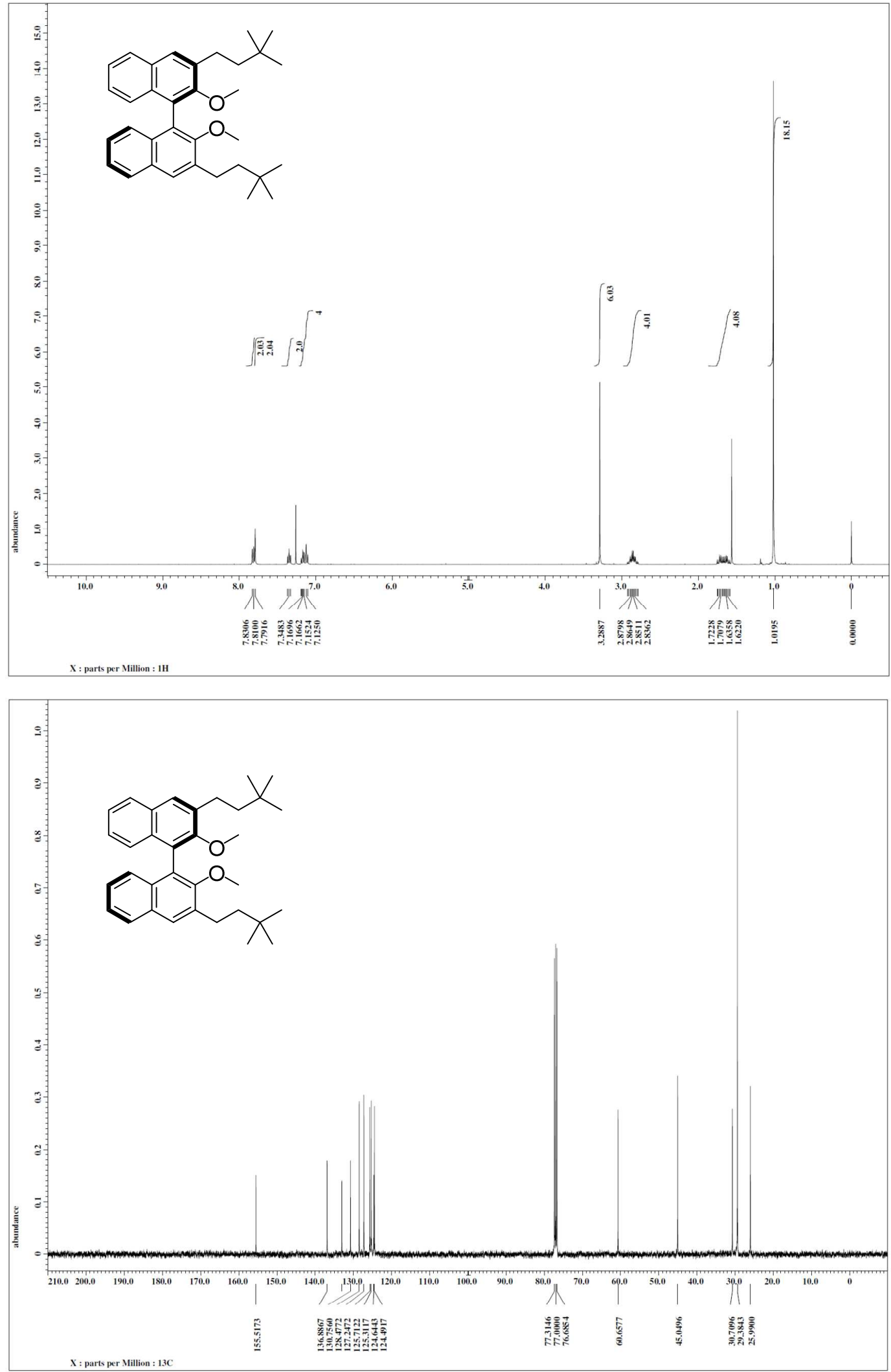
(R)-3,3'-Bis(3,3-dimethylbutyl)-2,2'-dihydroxy-1,1'-binaphthyl (3i)
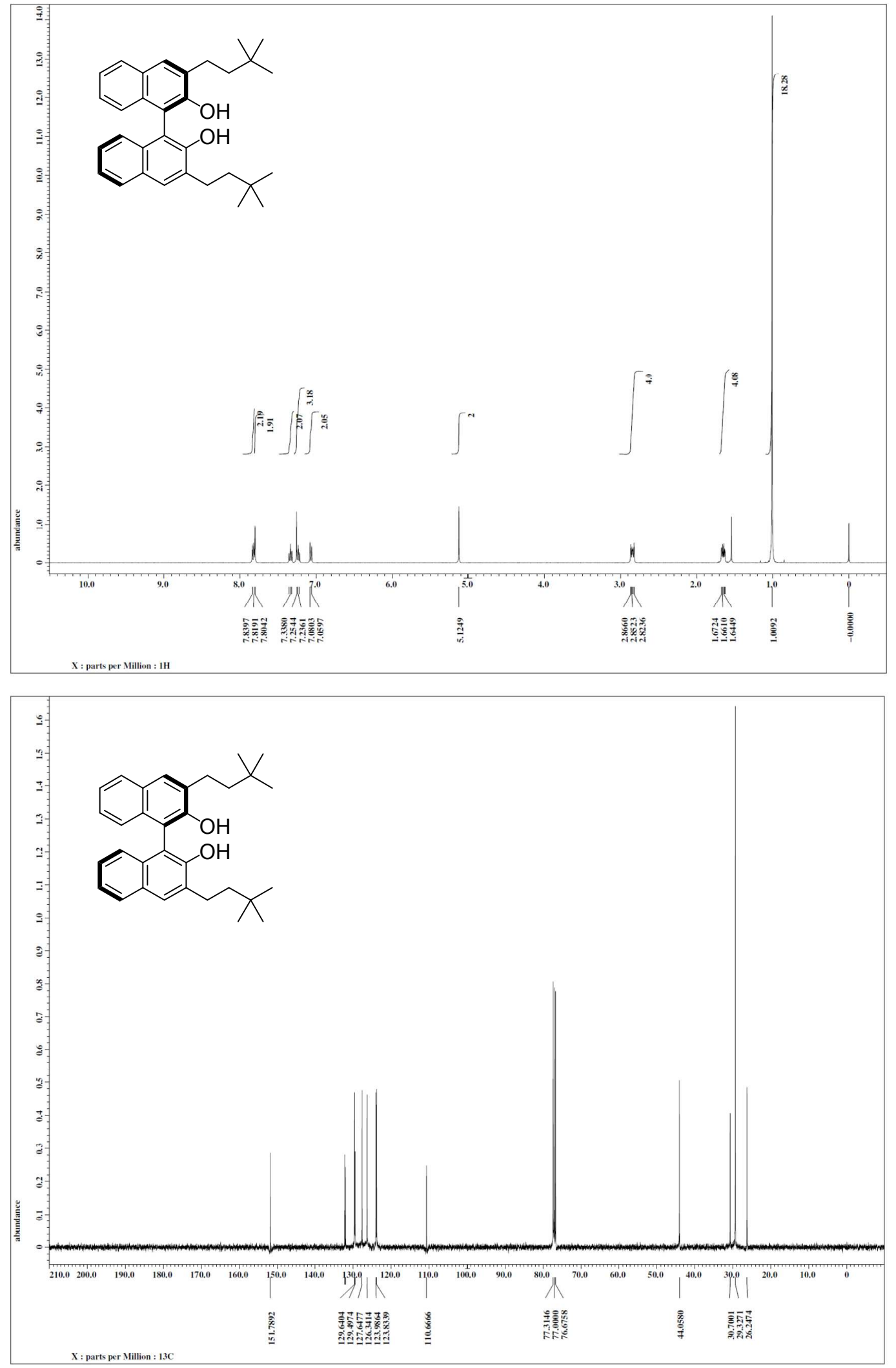


\section{$\underline{\text { HPLC Traces of Optically Active Compounds }}$}

(rac)-3,3'-Bis(3,3-dimethylbutyl)-2,2'-dihydroxy-1,1'-binaphthyl (3i)

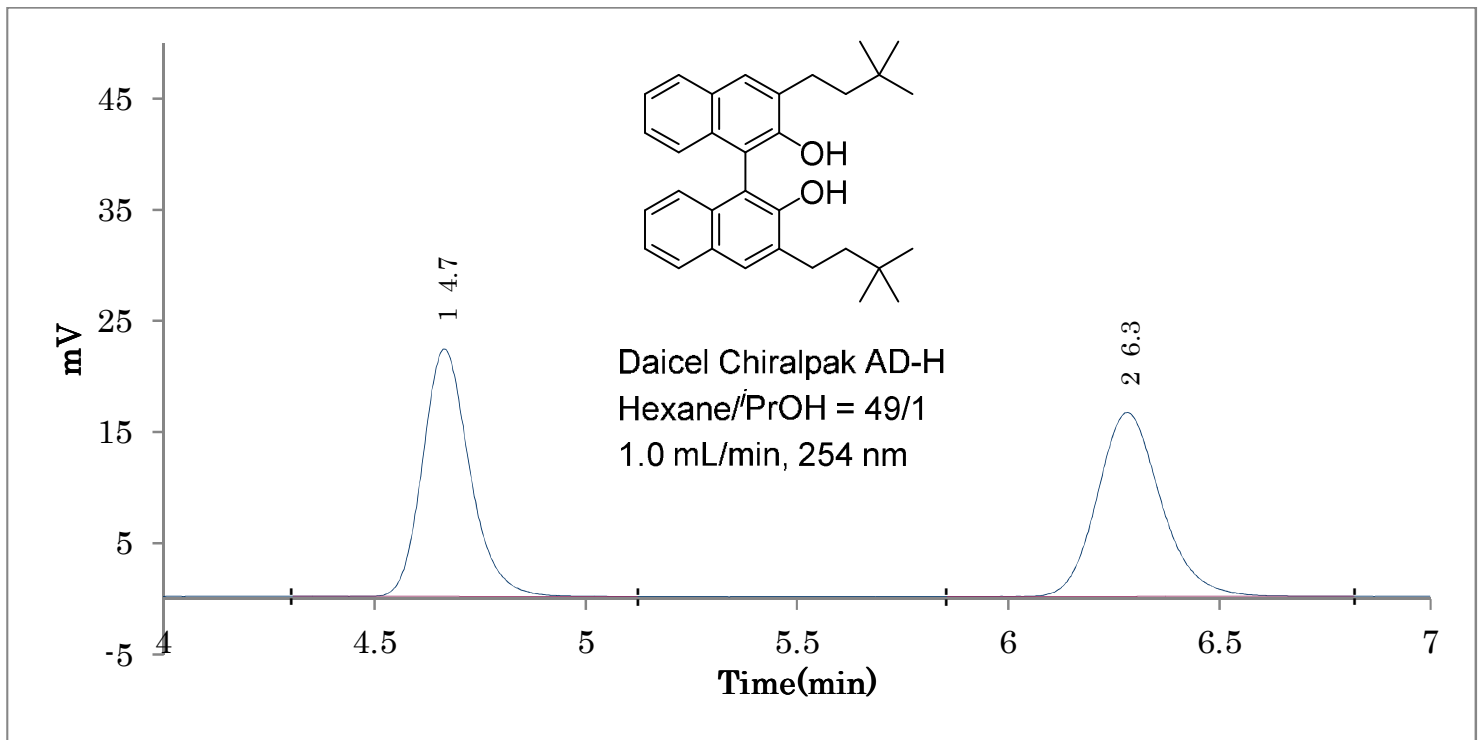

\begin{tabular}{|r|l|l|l|r|r|l|l|l|r|}
\hline No. & Rt & Peak Name & Area & Area(\%) & Height & Amount & NTP & Tf & Resolution \\
\hline 1 & 4.7 & & 171713.2 & 49.8572 & 22250 & ---- & 7975.8 & 1.193 & 6.574 \\
\hline 2 & 6.3 & & 172696.9 & 50.1428 & 16536 & ---- & 7880.8 & 1.154 & ---- \\
\hline & & & 344410.1 & 100 & 38786 & & & & \\
\hline
\end{tabular}

(R)-3,3'-Bis(3,3-dimethylbutyl)-2,2'-dihydroxy-1,1'-binaphthyl (3i)

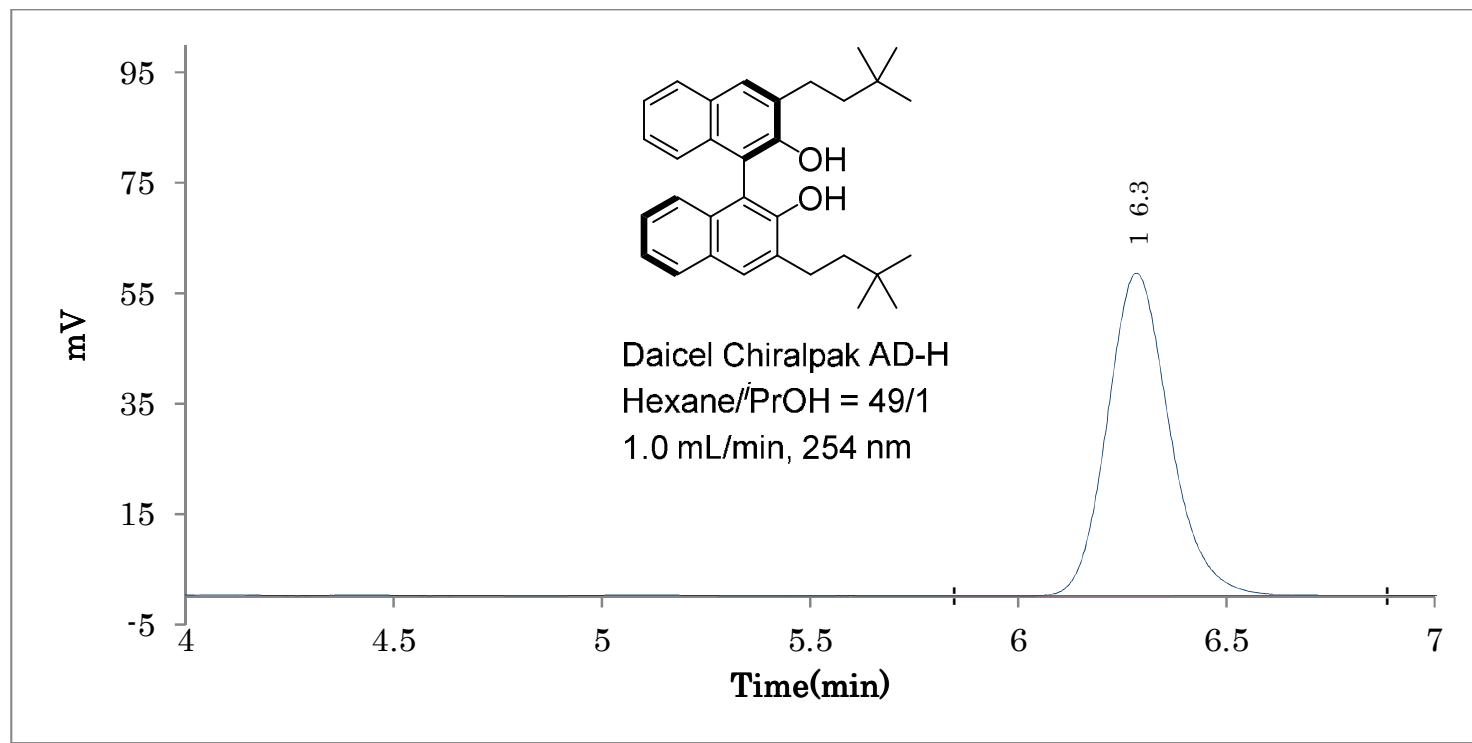

\begin{tabular}{|r|l|l|l|r|r|l|l|l|l|}
\hline No. & Rt & Peak Name & Area & Area(\%) & Height & Amount & NTP & Tf & Resolution \\
\hline 1 & 6.3 & & 607293.5 & 100 & 58451 & ---- & 8001 & 1.177 & ---- \\
\hline & & & 607293.5 & 100 & 58451 & & & & \\
\hline
\end{tabular}


(R)-1-(2-Naphthalenyl)-1-phenylethanol (4a)

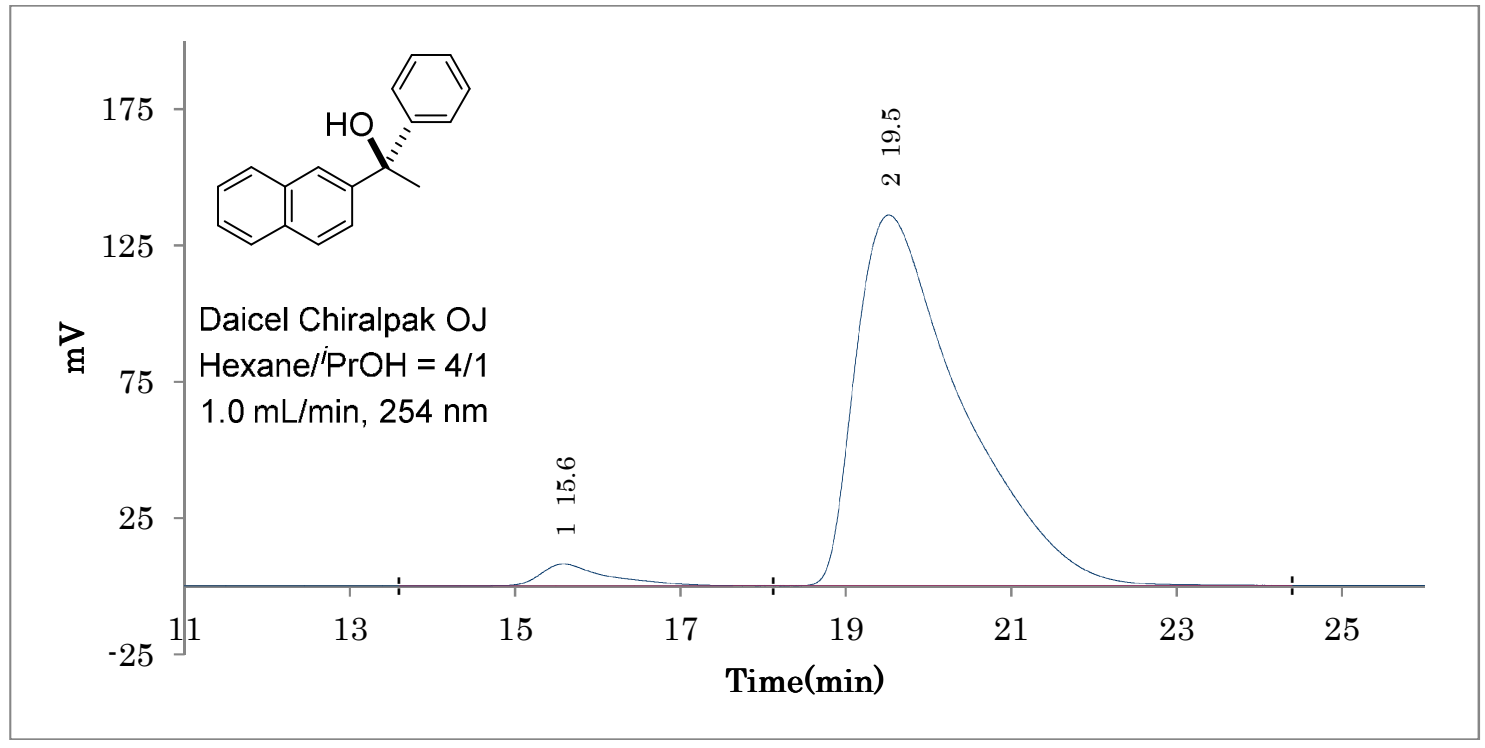

\begin{tabular}{|r|l|l|r|r|r|l|l|l|r|}
\hline No. & Rt & Peak Name & Area & Area(\%) & Height & Amount & NTP & Tf & Resolution \\
\hline 1 & 15.6 & & 443737.9 & 3.5514 & 7977 & ---- & 1775.9 & 1.826 & 2.05 \\
\hline 2 & 19.5 & & 12050867 & 96.4486 & 135916 & ---- & 1096.3 & 2.045 & ---- \\
\hline & & & 12494605 & 100 & 143893 & & & & \\
\hline
\end{tabular}

(S)-1-(2-Naphthalenyl)-1-phenylethanol (ent-4a)

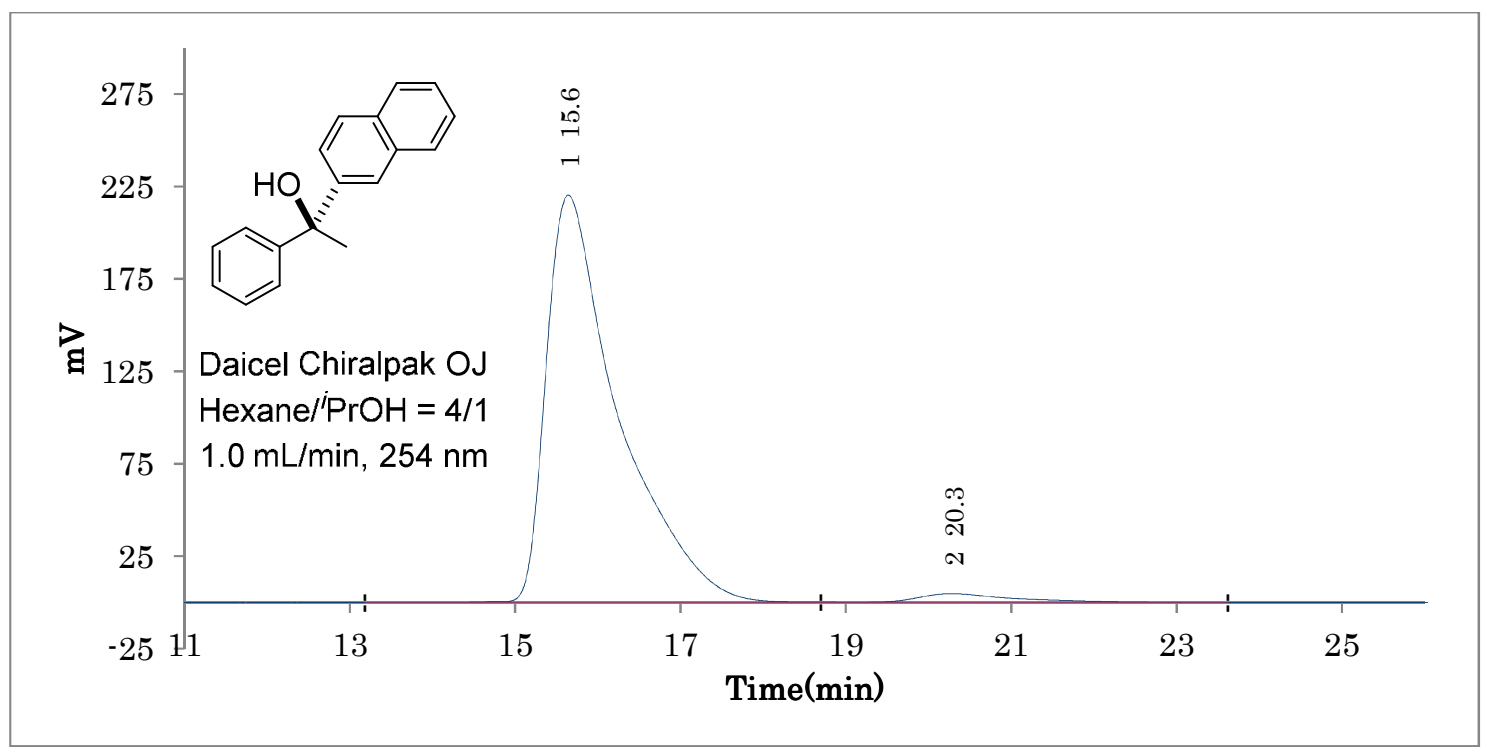

\begin{tabular}{|r|l|l|l|r|r|l|l|l|r|}
\hline No. & Rt & Peak Name & Area & Area(\%) & Height & Amount & NTP & Tf & Resolution \\
\hline 1 & 15.6 & & 13289129 & 97.1225 & 220402 & ---- & 1522.6 & 2.156 & 2.45 \\
\hline 2 & 20.3 & & 393726.3 & 2.8775 & 4790 & ---- & 1377.8 & 1.722 & ---- \\
\hline & & & 13682856 & 100 & 225192 & & & & \\
\hline
\end{tabular}


(R)-1-(1-Naphthalenyl)-1-phenylethanol (4b)

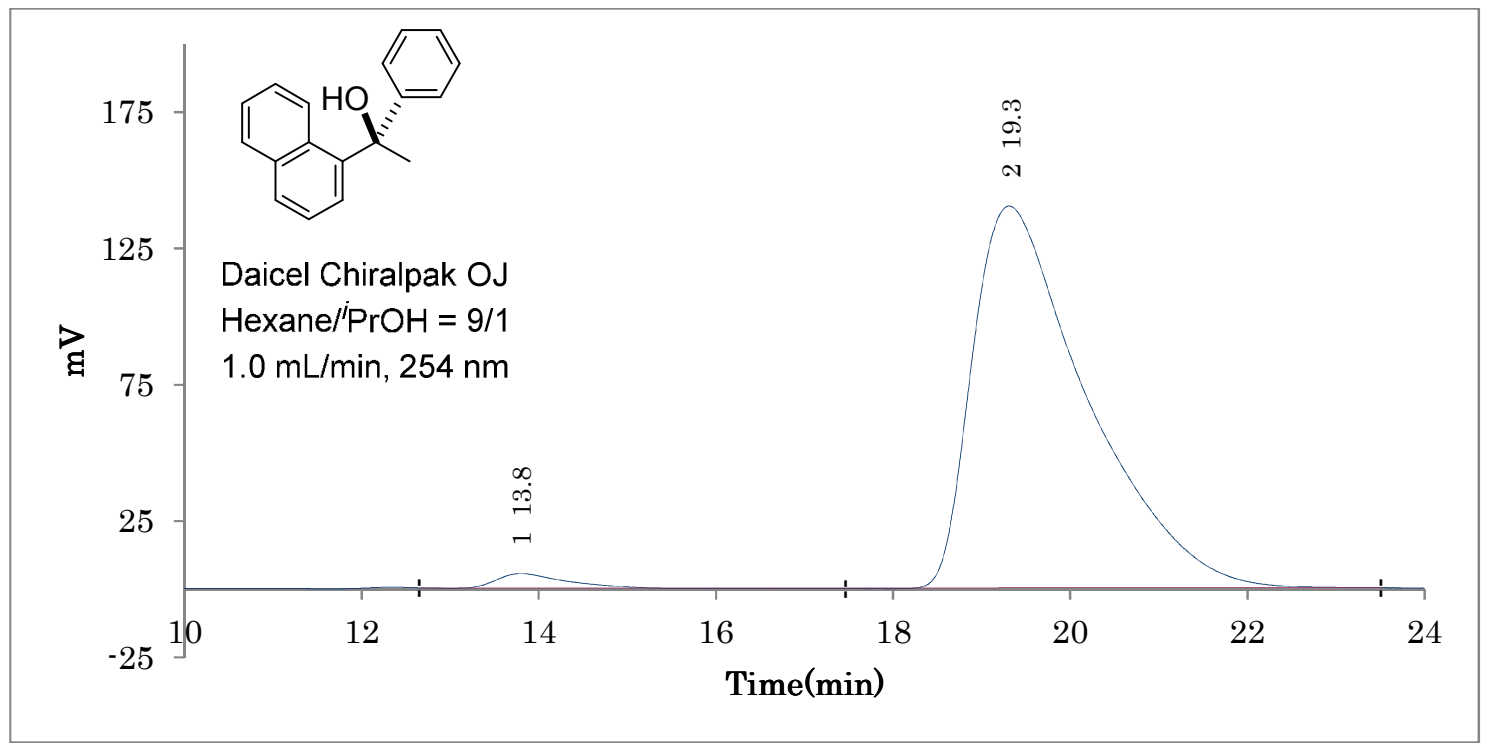

\begin{tabular}{|r|l|r|r|r|r|l|l|r|r|}
\hline No. & Rt & Peak Name & Area & Area(\%) & Height & Amount & NTP & Tf & Resolution \\
\hline 1 & 13.8 & & 240393 & 1.8833 & 5242 & ---- & 2044.3 & 1.69 & 3.071 \\
\hline 2 & 19.3 & & 12523740 & 98.1167 & 140096 & ---- & 1055.4 & 1.947 & ---- \\
\hline & & & 12764133 & 100 & 145338 & & & & \\
\hline
\end{tabular}


(R)-1-(4-Methoxyphenyl)-1-phenylethanol (4c)

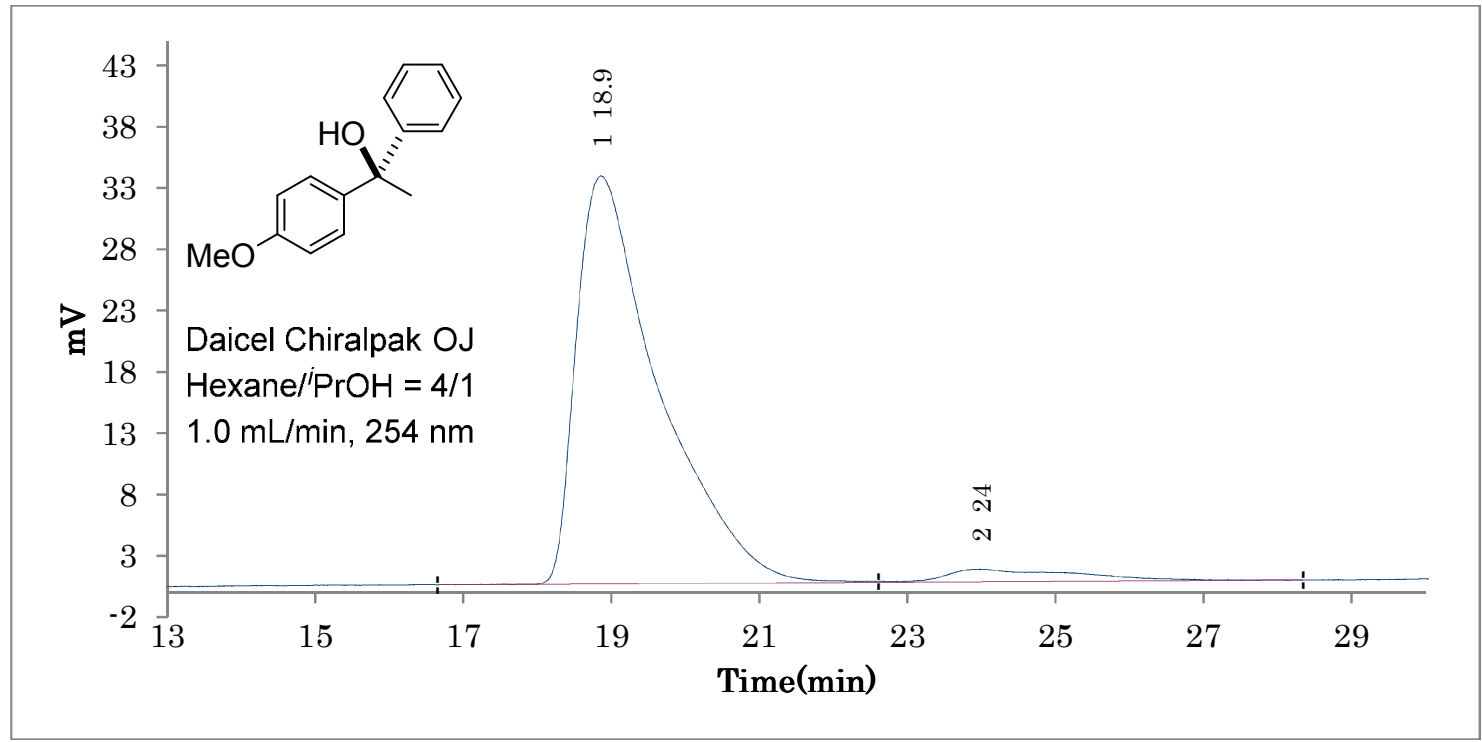

\begin{tabular}{|r|l|l|l|r|r|l|l|l|r|}
\hline No. & Rt & Peak Name & Area & Area(\%) & Height & Amount & NTP & Tf & Resolution \\
\hline 1 & 18.9 & & 2572058 & 95.356 & 33279 & ---- & 1345.5 & 2.244 & 1.931 \\
\hline 2 & 24 & & 125263.1 & 4.644 & 1024 & ---- & 869 & ---- & ---- \\
\hline & & & 2697321 & 100 & 34303 & & & & \\
\hline
\end{tabular}

(S)-1-(4-Methoxyphenyl)-1-phenylethanol (ent-4c)

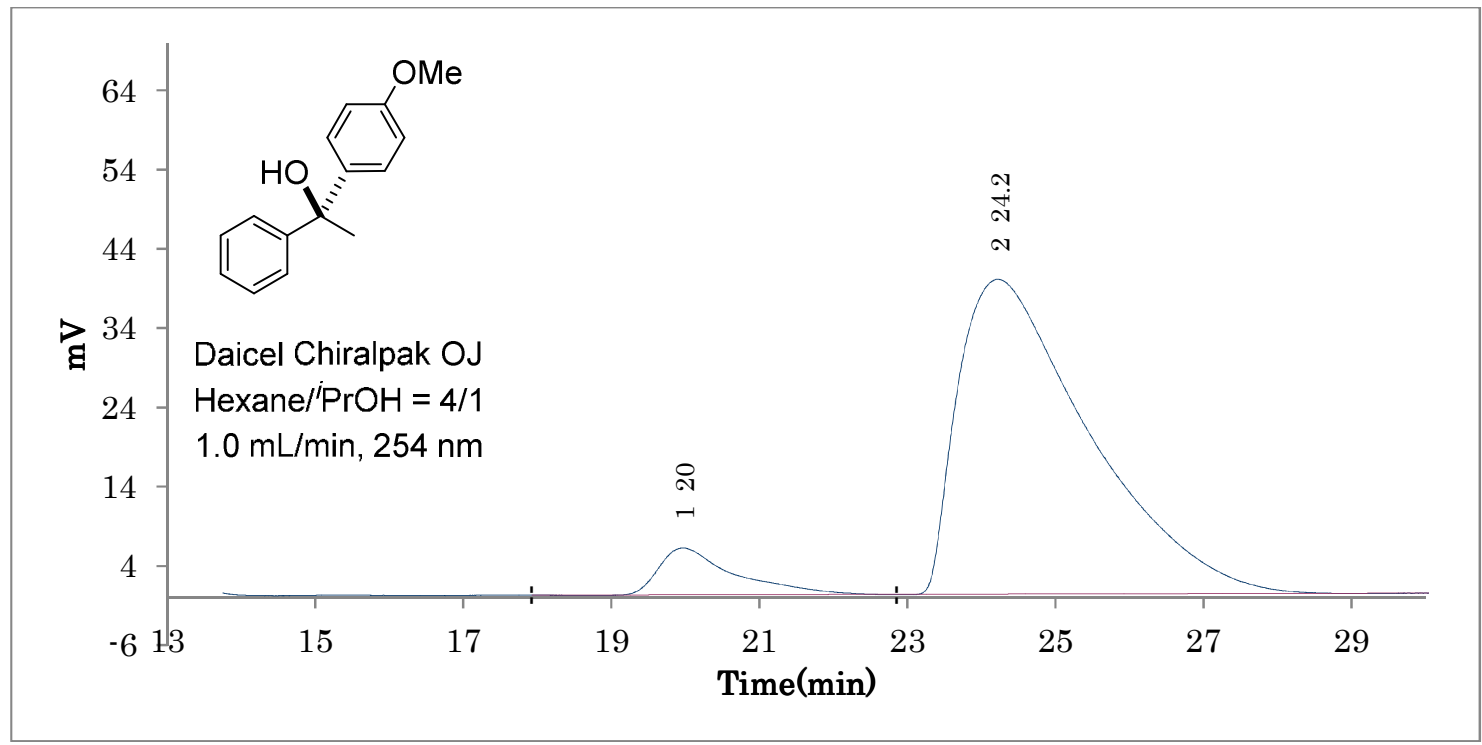

\begin{tabular}{|r|r|l|l|r|r|l|l|l|r|}
\hline No. & Rt & Peak Name & Area & Area(\%) & Height & Amount & NTP & Tf & Resolution \\
\hline 1 & 20 & & 410380.1 & 7.769 & 5903 & ---- & 1866.4 & 2.034 & 1.667 \\
\hline 2 & 24.2 & & 4871926 & 92.231 & 39708 & ---- & 882.2 & 2.225 & ---- \\
\hline & & & 5282307 & 100 & 45611 & & & & \\
\hline
\end{tabular}


(R)-1-(4-Bromophenyl)-1-phenylethanol (4d)

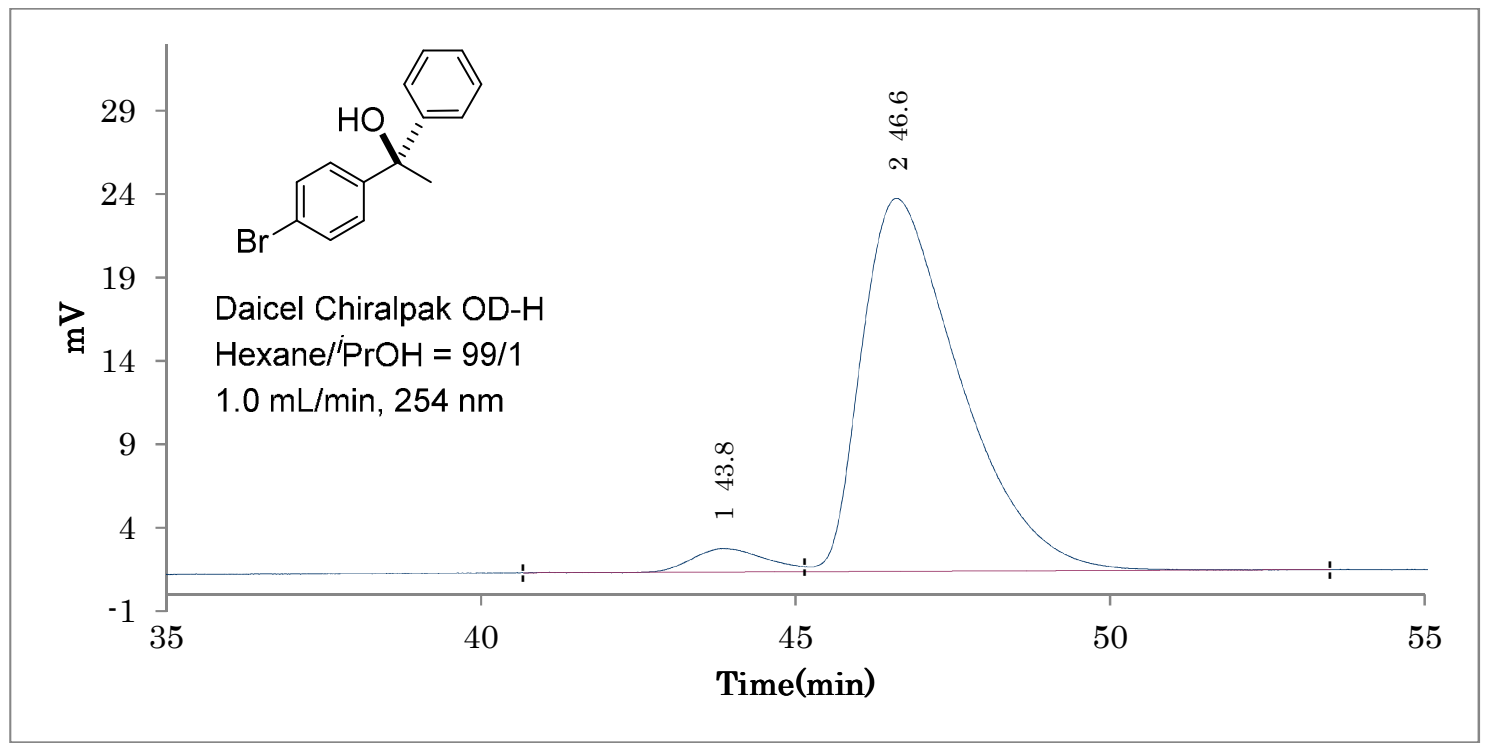

\begin{tabular}{|r|l|l|l|r|r|l|l|l|r|}
\hline No. & Rt & Peak Name & Area & Area(\%) & Height & Amount & NTP & Tf & Resolution \\
\hline 1 & 43.8 & & 112122.1 & 4.4144 & 1399 & ---- & 6765.2 & ---- & 1.105 \\
\hline 2 & 46.6 & & 2427806 & 95.5856 & 22363 & ---- & 4168.2 & 1.728 & ---- \\
\hline & & & 2539928 & 100 & 23762 & & & & \\
\hline
\end{tabular}


(R)-1-(4-Chlorophenyl)-1-phenylethanol (4e)

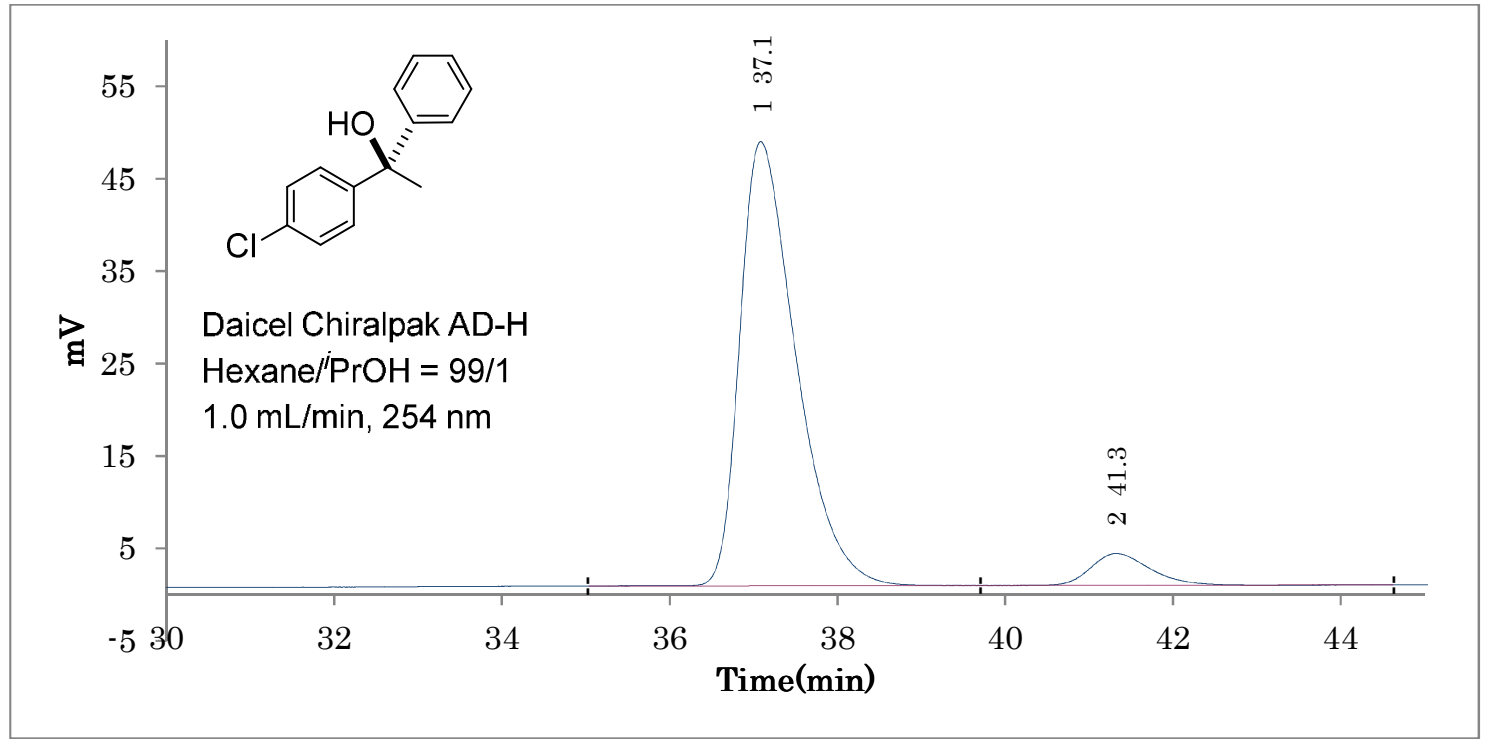

\begin{tabular}{|r|l|l|l|r|r|l|l|l|r|}
\hline No. & Rt & Peak Name & Area & Area(\%) & Height & Amount & NTP & Tf & Resolution \\
\hline 1 & 37.1 & & 2227456 & 93.0128 & 48056 & ---- & 14478.3 & 1.556 & 3.343 \\
\hline 2 & 41.3 & & 167327.1 & 6.9872 & 3435 & ---- & 16267.2 & 1.321 & ---- \\
\hline & & & 2394783 & 100 & 51491 & & & & \\
\hline
\end{tabular}

(S)-1-(4-Chlorophenyl)-1-phenylethanol (ent-4e)

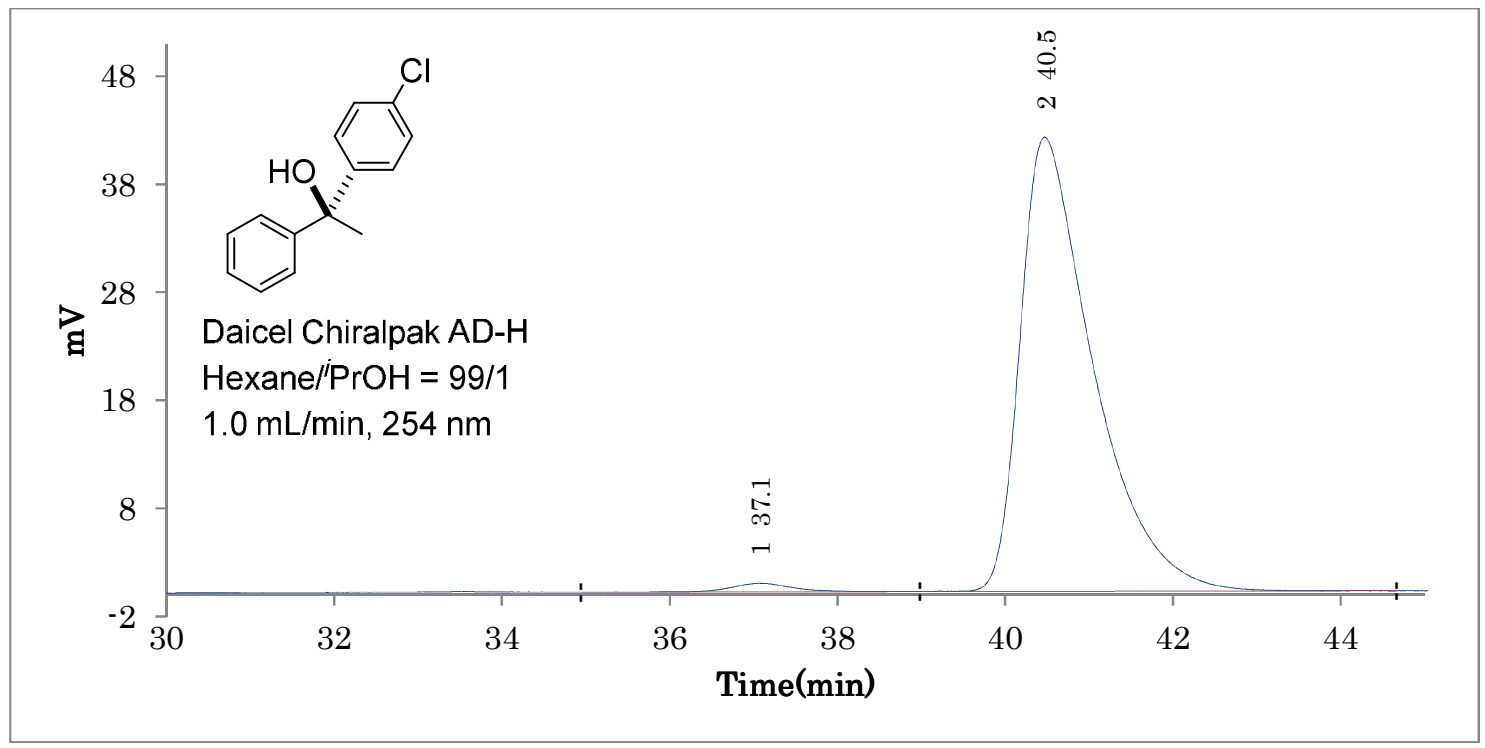

\begin{tabular}{|r|l|l|l|r|r|l|l|l|r|}
\hline No. & Rt & Peak Name & Area & Area(\%) & Height & Amount & NTP & Tf & Resolution \\
\hline 1 & 37.1 & & 39264.6 & 1.5242 & 785 & ---- & 12417.4 & 1.194 & 2.32 \\
\hline 2 & 40.5 & & 2536800 & 98.4758 & 42014 & ---- & 10160 & 1.813 & ---- \\
\hline & & & 2576065 & 100 & 42799 & & & & \\
\hline
\end{tabular}


(rac)-1-(2-Naphthalenyl)-1-phenylpropanol (4f)

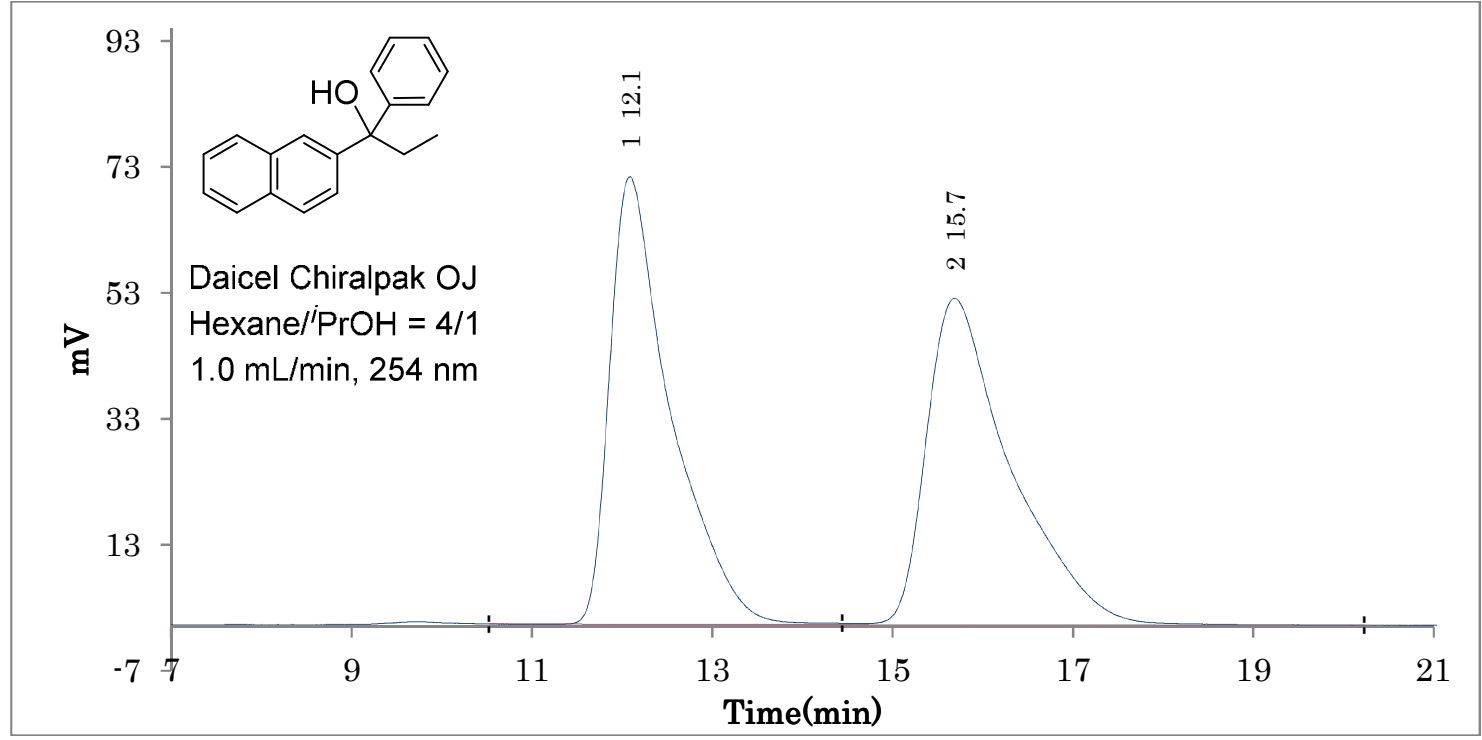

\begin{tabular}{|r|l|l|l|r|r|l|l|l|r|}
\hline No. & Rt & Peak Name & Area & Area(\%) & Height & Amount & NTP & Tf & Resolution \\
\hline 1 & 12.1 & & 3321760 & 49.8473 & 70998 & ---- & 1508.7 & 1.876 & 2.432 \\
\hline 2 & 15.7 & & 3342112 & 50.1527 & 51781 & ---- & 1335.5 & 1.819 & ---- \\
\hline & & & 6663872 & 100 & 122779 & & & & \\
\hline
\end{tabular}

(R)-1-(2-Naphthalenyl)-1-phenylpropanol (4f)

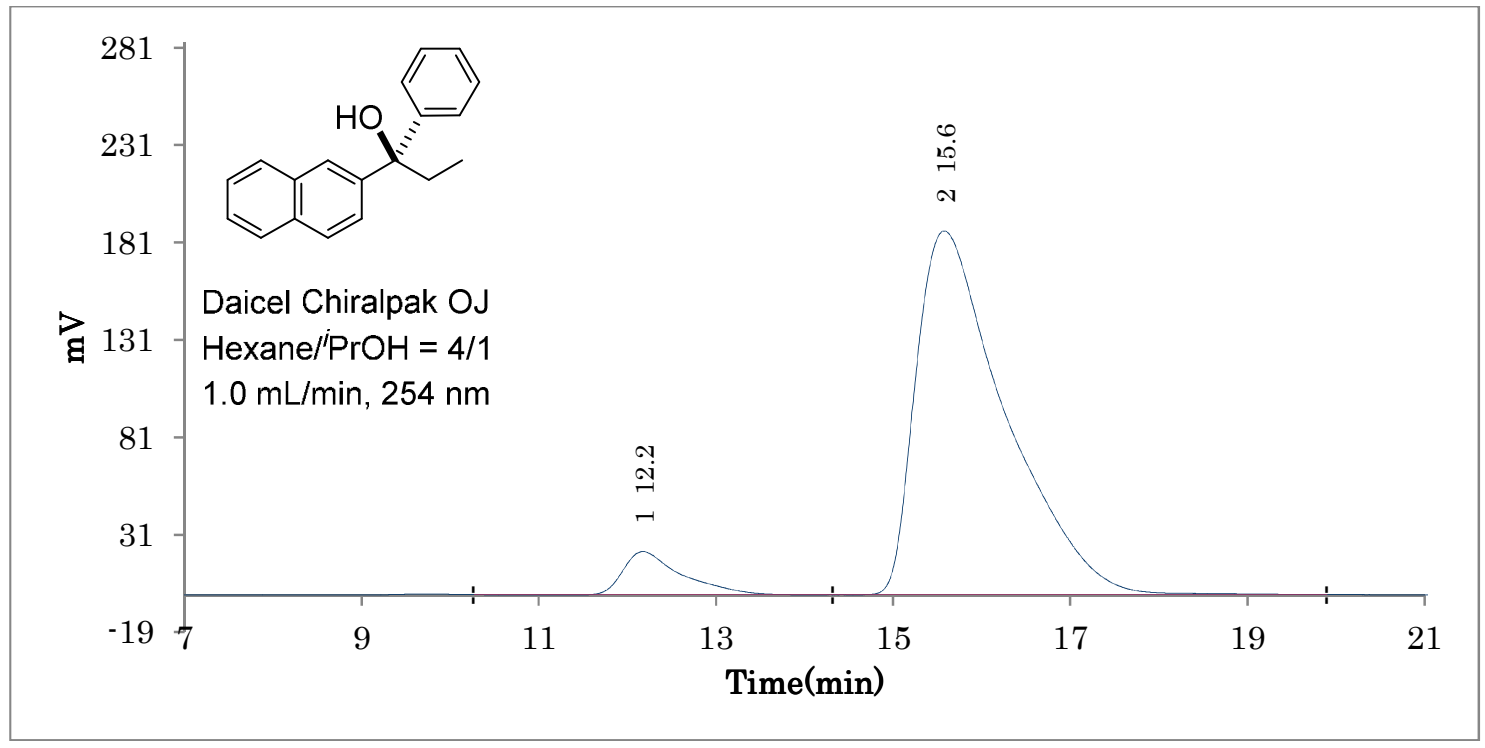

\begin{tabular}{|r|l|l|r|r|r|l|l|r|r|}
\hline No. & Rt & Peak Name & Area & Area(\%) & Height & Amount & NTP & Tf & Resolution \\
\hline 1 & 12.2 & & 979699.8 & 6.9902 & 21970 & --- & 1686.6 & 1.789 & 2.234 \\
\hline 2 & 15.6 & & 13035555 & 93.0098 & 186658 & ---- & 1125.3 & 1.97 & ---- \\
\hline & & & 14015255 & 100 & 208628 & & & & \\
\hline
\end{tabular}




\section{(S)-1-Cyclohexyl-1-phenylethanol (4g)}

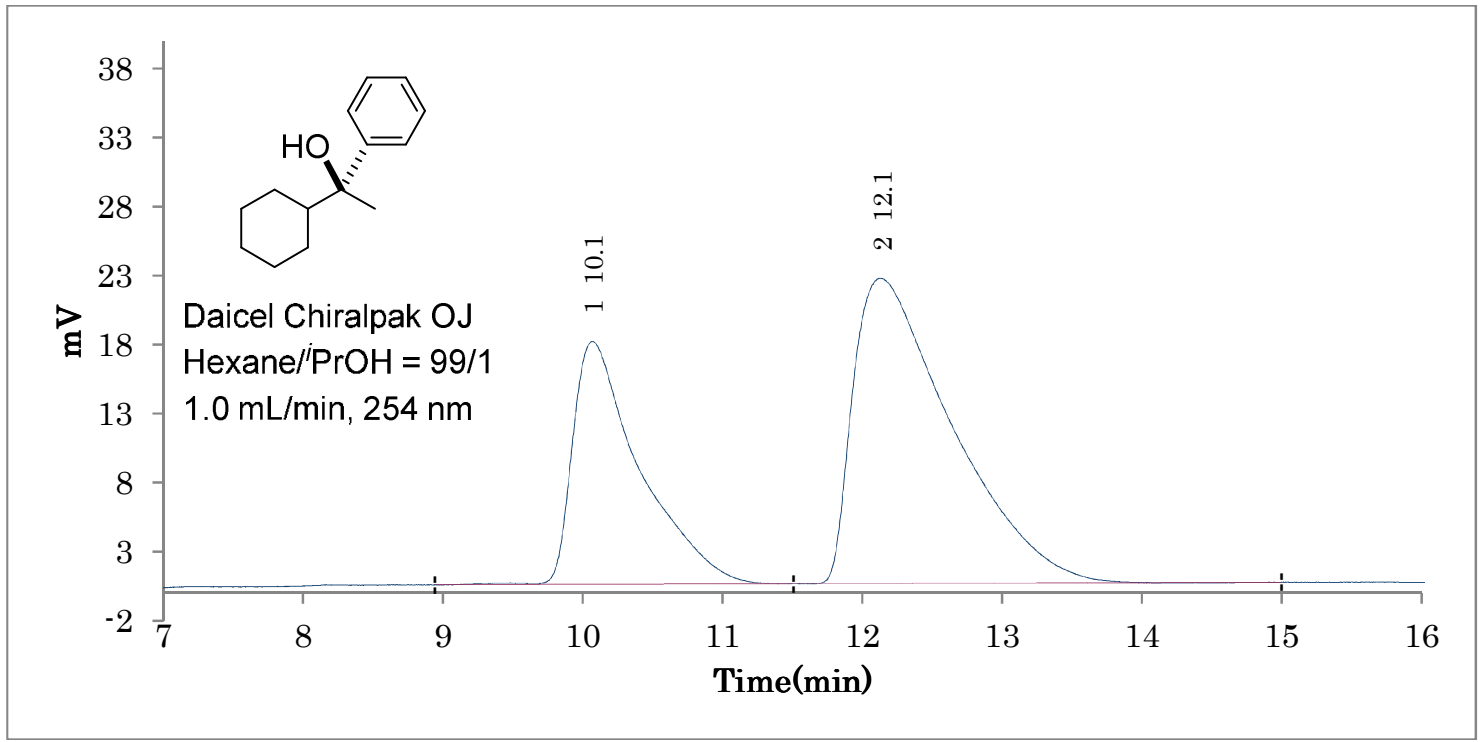

\begin{tabular}{|r|l|l|l|r|r|l|l|l|r|}
\hline No. & Rt & Peak Name & Area & Area(\%) & Height & Amount & NTP & Tf & Resolution \\
\hline 1 & 10.1 & & 585313.6 & 35.0904 & 17600 & ---- & 2072.5 & 2.207 & 1.887 \\
\hline 2 & 12.1 & & 1082704 & 64.9096 & 22102 & ---- & 1386.9 & 2.356 & ---- \\
\hline & & & 1668018 & 100 & 39702 & & & & \\
\hline
\end{tabular}

\section{(R)-1-Cyclohexyl-1-phenylethanol (ent-4g)}

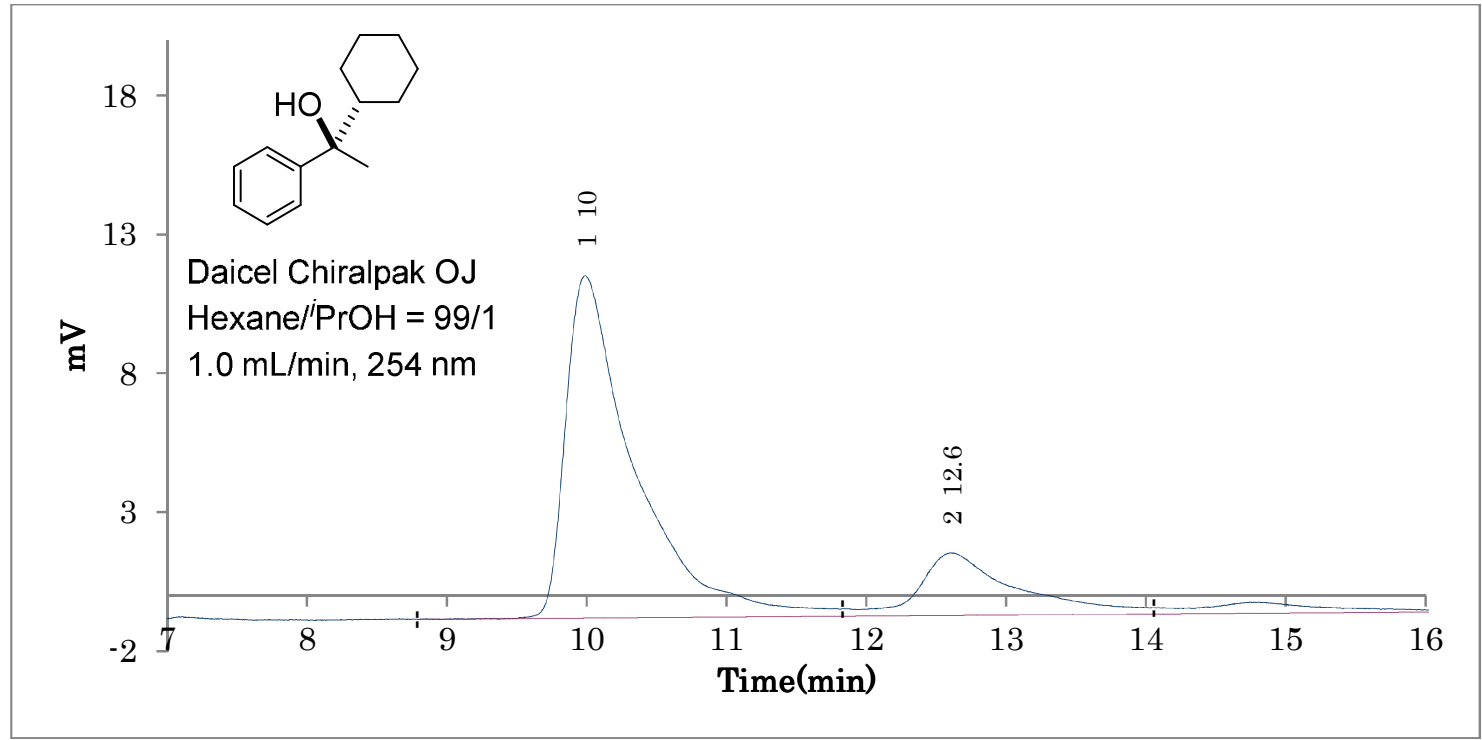

\begin{tabular}{|r|r|l|l|l|r|l|l|l|r|}
\hline No. & Rt & Peak Name & Area & Area(\%) & Height & Amount & NTP & Tf & Resolution \\
\hline 1 & 10 & & 421662.1 & 79.4722 & 12321 & ---- & 1926.1 & 2.593 & 2.38 \\
\hline 2 & 12.6 & & 108915.7 & 20.5278 & 2252 & ---- & 1535.2 & ---- & ---- \\
\hline & & & 530577.9 & 100 & 14573 & & & & \\
\hline
\end{tabular}


(S)-1-(3-Methoxyphenyl)-1-phenylethanol (4h)

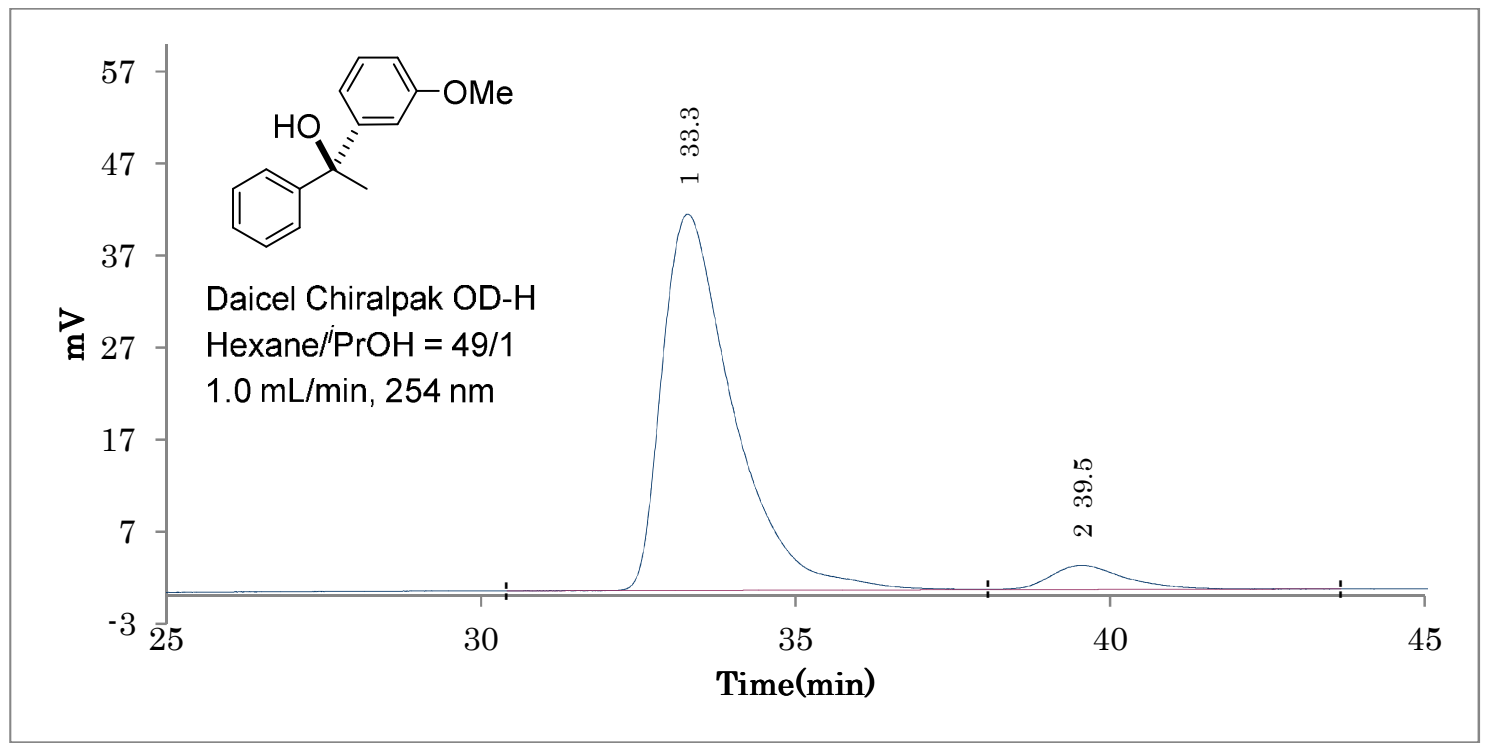

\begin{tabular}{|r|l|l|l|r|r|l|l|l|r|}
\hline No. & Rt & Peak Name & Area & Area(\%) & Height & Amount & NTP & Tf & Resolution \\
\hline 1 & 33.3 & & 3202441 & 93.6906 & 40902 & ---- & 4087.5 & 1.772 & 2.937 \\
\hline 2 & 39.5 & & 215660 & 6.3094 & 2638 & ---- & 5289.6 & 1.411 & ---- \\
\hline & & & 3418101 & 100 & 43540 & & & & \\
\hline
\end{tabular}


(S)-1-(2-Methoxyphenyl)-1-phenylethanol (4i)

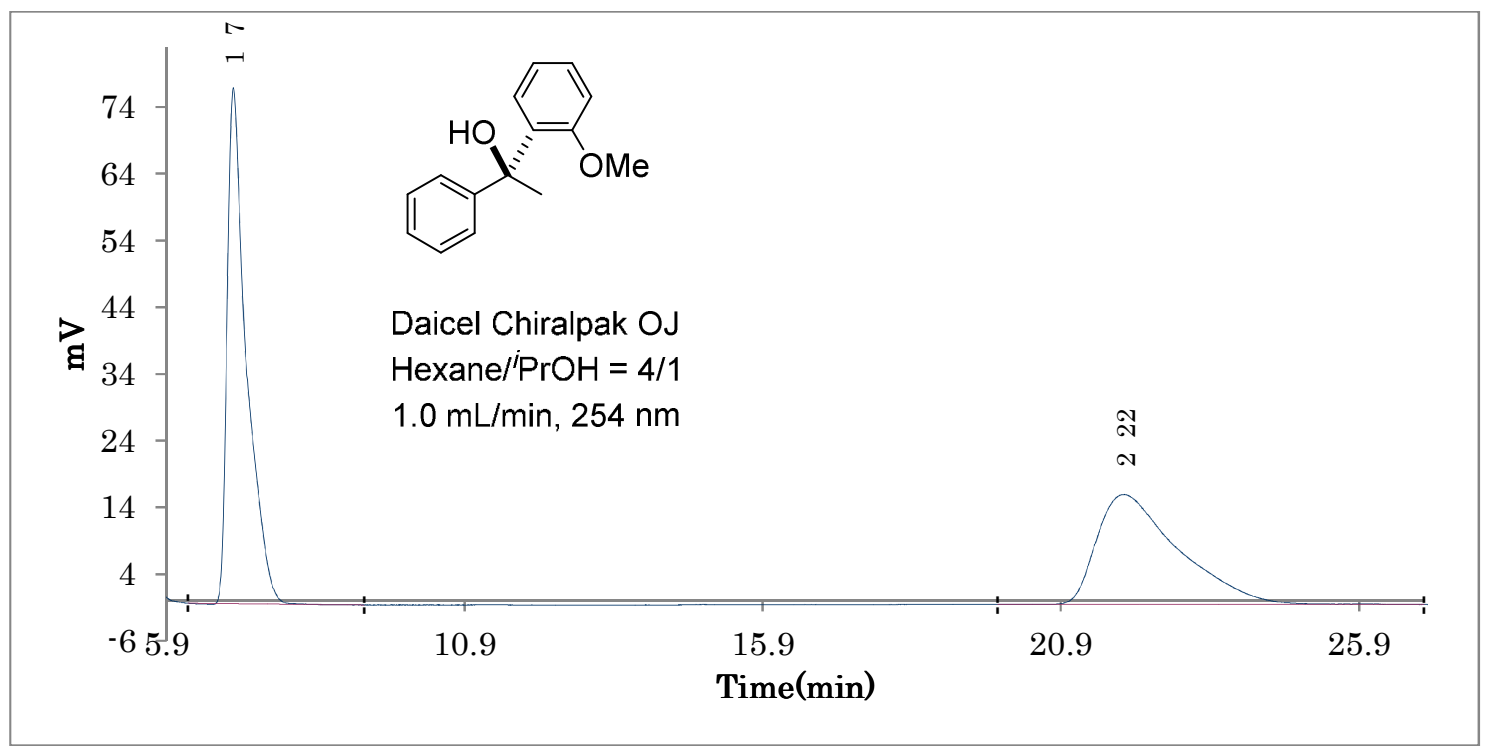

\begin{tabular}{|r|r|l|l|r|r|l|l|l|r|}
\hline No. & Rt & Peak Name & Area & Area(\%) & Height & Amount & NTP & Tf & Resolution \\
\hline 1 & 7 & & 1743767 & 52.8536 & 77376 & ---- & 1698.5 & 1.977 & 8.932 \\
\hline 2 & 22 & & 1555470 & 47.1464 & 16469 & ---- & 1086.9 & 1.82 & ---- \\
\hline & & & 3299238 & 100 & 93845 & & & & \\
\hline
\end{tabular}


(S)-1-(4-Methylphenyl)-1-phenylethanol (4j)

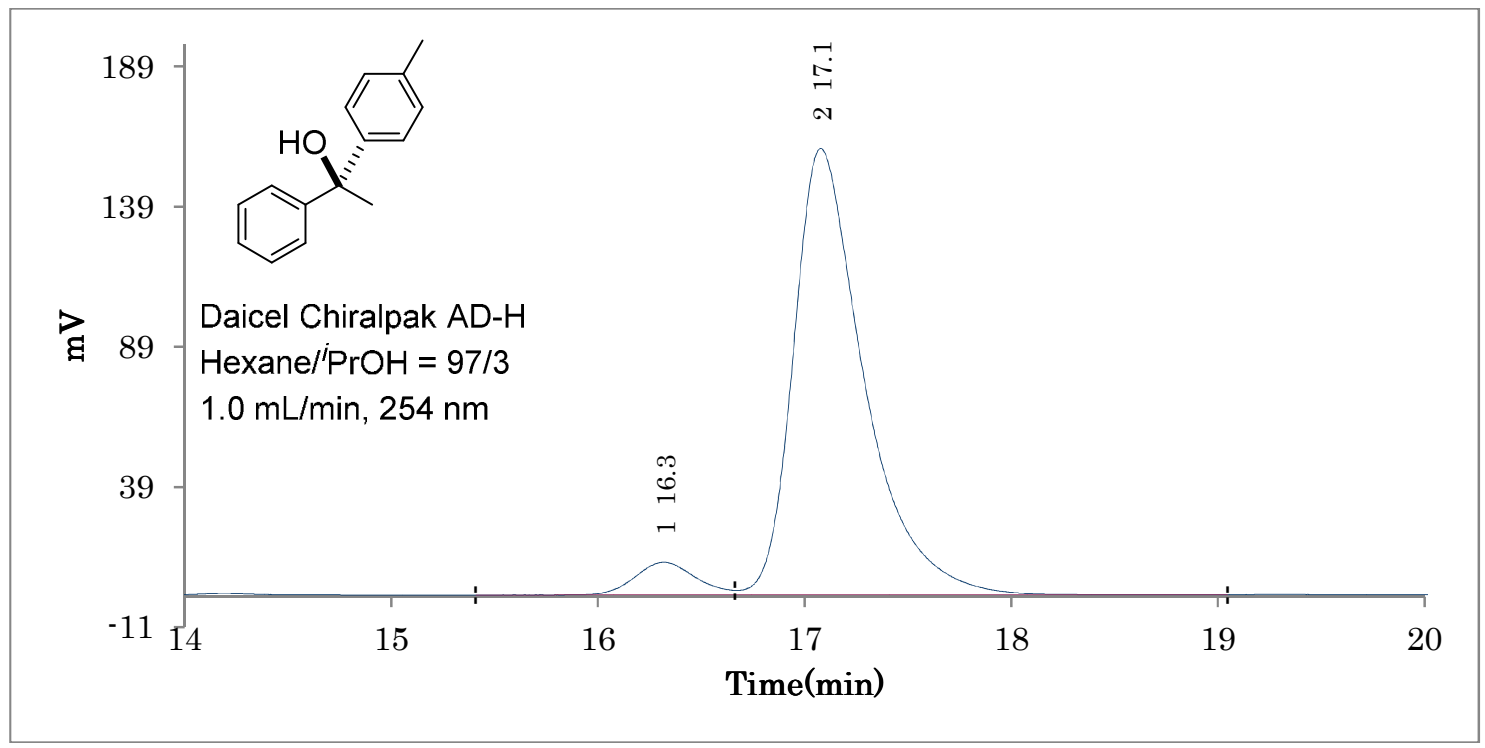

\begin{tabular}{|r|l|l|l|r|r|l|l|l|r|}
\hline No. & Rt & Peak Name & Area & Area(\%) & Height & Amount & NTP & Tf & Resolution \\
\hline 1 & 16.3 & & 236305.7 & 5.8924 & 11625 & ---- & 14580.1 & ---- & 1.292 \\
\hline 2 & 17.1 & & 3774031 & 94.1076 & 159161 & ---- & 11731.4 & 1.554 & ---- \\
\hline & & & 4010337 & 100 & 170786 & & & & \\
\hline
\end{tabular}


(S)-1-(2-Methylphenyl)-1-phenylethanol (4k)

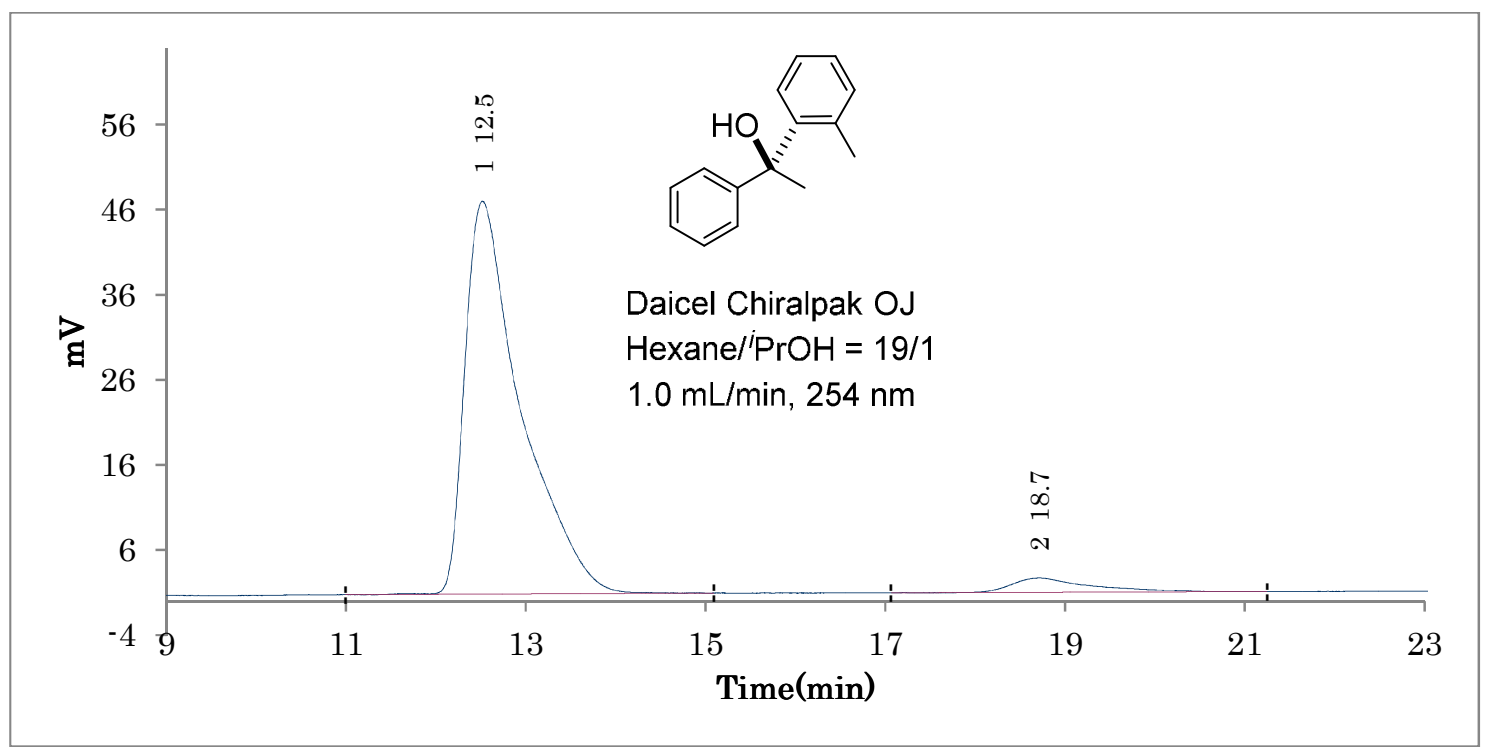

\begin{tabular}{|r|l|l|l|r|r|l|l|l|r|}
\hline No. & Rt & Peak Name & Area & Area(\%) & Height & Amount & NTP & Tf & Resolution \\
\hline 1 & 12.5 & & 1992217 & 95.179 & 46167 & ---- & 1496.9 & 2.082 & 3.939 \\
\hline 2 & 18.7 & & 100909.6 & 4.821 & 1681 & ---- & 1638.8 & 1.864 & ---- \\
\hline & & & 2093127 & 100 & 47848 & & & & \\
\hline
\end{tabular}


(S)-1-(4-Fluorophenyl)-1-phenylethanol (4I)

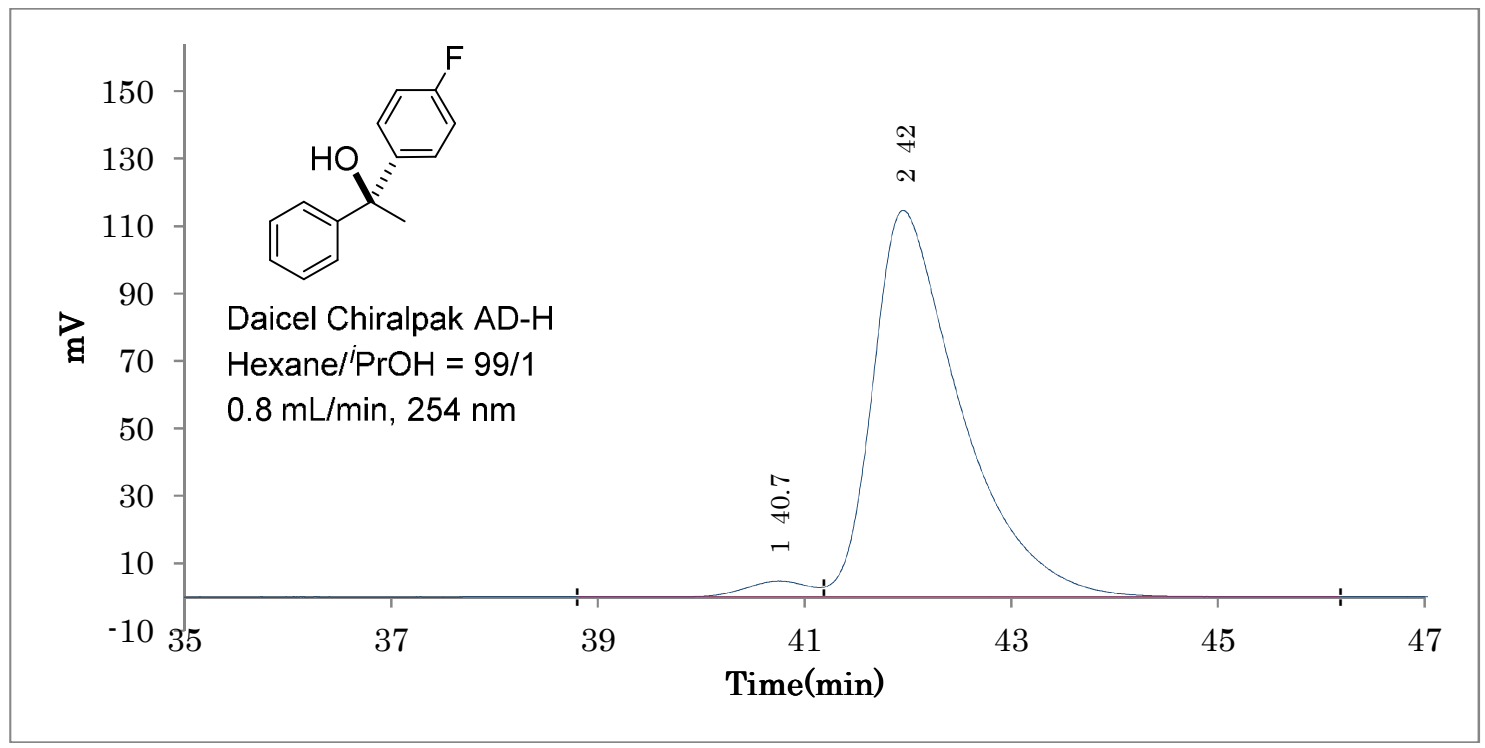

\begin{tabular}{|r|l|l|l|r|r|l|l|l|r|}
\hline No. & Rt & Peak Name & Area & Area(\%) & Height & Amount & NTP & Tf & Resolution \\
\hline 1 & 40.7 & & 198274.6 & 2.8545 & 4620 & ---- & 20383.3 & ---- & 0.899 \\
\hline 2 & 42 & & 6747873 & 97.1455 & 114614 & ---- & 11487.5 & 1.694 & ---- \\
\hline & & & 6946148 & 100 & 119234 & & & & \\
\hline
\end{tabular}




\section{$\underline{\text { References }}$}

${ }^{1} \mathrm{Wu}, \mathrm{T}$. R.; Shen, L.; Chong, J. M. Org. Lett. 2004, 6, 2701-2704.

${ }^{2}$ Simonsen, K. B.; Gothelf, K. V.; Jørgensen, K. A. J. Org. Chem. 1998, 63, 7536-7538.

${ }^{3}$ Lukas, R. J.; Muresan, A. Z.; Imad Damaj, M.; Blough, B. E.; Huang, X.; Navarro, H. A.; Wayne Mascarella, S.; Brek Eaton, J.; Marxer-Miller, S. K.; Ivy Carroll, F. J. Med. Chem. 2010, 53, 4731-4748.

${ }^{4}$ Chen, C.-A.; Wu, K.-H.; Gau, H.-M. Adv. Synth. Catal. 2008, 350, 1626-1634.

${ }^{5}$ Forrat, V. J.; Prieto, O.; Ramón, D. J.; Yus, M. Chem. Eur. J. 2006, 12, 4431-4445.

${ }^{6}$ Stymiest, J. L.; Bagutski, V.; French, R. M.; Aggarwal, V. K. Nature 2008, 456, 778-782.

${ }^{7}$ Dosa, P. I.; Fu, G. C. J. Am. Chem. Soc. 1998, 120, 445-446.

${ }^{8}$ Bagutski, V.; French, R. M.; Aggarwal, V. K. Angew. Chem. Int. Ed. 2010, 49, 5142-5145. 